\title{
Global Budget of Methanol: Constraints from Atmospheric Observations
}

\section{Citation}

Jacob, Daniel J., Brendan D. Field, Qinbin Li, Donald R. Blake, Joost de Gouw, Carsten Warneke, Armin Hansel, Armin Wisthaler, Hanwant B. Singh, and A. Guenther. 2005. Global budget of methanol: Constraints from atmospheric observations. Journal of Geophysical Research 110(D08303): 1-17.

\section{Published Version}

doi:10.1029/2004JD005172

\section{Permanent link}

http://nrs.harvard.edu/urn-3:HUL.InstRepos:3988781

\section{Terms of Use}

This article was downloaded from Harvard University's DASH repository, and is made available under the terms and conditions applicable to Other Posted Material, as set forth at http:// nrs.harvard.edu/urn-3:HUL.InstRepos:dash.current.terms-of-use\#LAA

\section{Share Your Story}

The Harvard community has made this article openly available.

Please share how this access benefits you. Submit a story.

\section{Accessibility}




\title{
Global budget of methanol: Constraints from atmospheric observations
}

\author{
Daniel J. Jacob, ${ }^{1}$ Brendan D. Field, ${ }^{1}$ Qinbin Li, ${ }^{1,2}$ Donald R. Blake, ${ }^{3}$ Joost de Gouw, ${ }^{4}$ \\ Carsten Warneke, ${ }^{4}$ Armin Hansel, ${ }^{5}$ Armin Wisthaler, ${ }^{5}$ Hanwant B. Singh, ${ }^{6}$ \\ and A. Guenther ${ }^{7}$
}

Received 28 June 2004; revised 5 January 2005; accepted 2 February 2005; published 26 April 2005.

[1] We use a global three-dimensional model simulation of atmospheric methanol to examine the consistency between observed atmospheric concentrations and current understanding of sources and sinks. Global sources in the model include $128 \mathrm{Tg} \mathrm{yr}^{-1}$ from plant growth, $38 \mathrm{Tg} \mathrm{yr}^{-1}$ from atmospheric reactions of $\mathrm{CH}_{3} \mathrm{O}_{2}$ with itself and other organic peroxy radicals, $23 \mathrm{Tg} \mathrm{yr}^{-1}$ from plant decay, $13 \mathrm{Tg} \mathrm{yr}^{-1}$ from biomass burning and biofuels, and $4 \mathrm{Tg} \mathrm{yr}^{-1}$ from vehicles and industry. The plant growth source is a factor of 3 higher for young than from mature leaves. The atmospheric lifetime of methanol in the model is 7 days; gas-phase oxidation by $\mathrm{OH}$ accounts for $63 \%$ of the global sink, dry deposition to land $26 \%$, wet deposition $6 \%$, uptake by the ocean $5 \%$, and aqueous-phase oxidation in clouds less than $1 \%$. The resulting simulation of atmospheric concentrations is generally unbiased in the Northern Hemisphere and reproduces the observed correlations of methanol with acetone, $\mathrm{HCN}$, and $\mathrm{CO}$ in Asian outflow. Accounting for decreasing emission from leaves as they age is necessary to reproduce the observed seasonal variation of methanol concentrations at northern midlatitudes. The main model discrepancy is over the South Pacific, where simulated concentrations are a factor of 2 too low. Atmospheric production from the $\mathrm{CH}_{3} \mathrm{O}_{2}$ self-reaction is the dominant model source in this region. A factor of 2 increase in this source (to $50-100 \mathrm{Tg}$ $\mathrm{yr}^{-1}$ ) would largely correct the discrepancy and appears consistent with independent constraints on $\mathrm{CH}_{3} \mathrm{O}_{2}$ concentrations. Our resulting best estimate of the global source of methanol is $240 \mathrm{Tg} \mathrm{yr}^{-1}$. More observations of methanol concentrations and fluxes are needed over tropical continents. Better knowledge is needed of $\mathrm{CH}_{3} \mathrm{O}_{2}$ concentrations in the remote troposphere and of the underlying organic chemistry.

Citation: Jacob, D. J., B. D. Field, Q. Li, D. R. Blake, J. de Gouw, C. Warneke, A. Hansel, A. Wisthaler, H. B. Singh, and A. Guenther (2005), Global budget of methanol: Constraints from atmospheric observations, J. Geophys. Res., 110, D08303, doi:10.1029/2004JD005172.

\section{Introduction}

[2] Methanol is the second most abundant organic gas in the atmosphere after methane. It is present at typical concentrations of $1-10 \mathrm{ppbv}$ in the continental boundary layer and $0.1-1 \mathrm{ppbv}$ in the remote troposphere [Singh et al., 1995; Heikes et al., 2002]. It is a significant atmospheric source of formaldehyde [Riemer et al., 1998; Palmer et al., 2003a] and CO (B. N. Duncan et al., Global model study of

\footnotetext{
${ }^{1}$ Division of Engineering and Applied Science, Harvard University, Cambridge, Massachusetts, USA.

${ }^{2}$ Now at Jet Propulsion Laboratory, Pasadena, California, USA.

${ }^{3}$ Department of Chemistry, University of California, Irvine, California, USA.

${ }^{4}$ NOAA Aeronomy Laboratory, Boulder, Colorado, USA

${ }^{5}$ Institute of Ion Physics, University of Innsbruck, Innsbruck, Austria.

${ }^{6}$ NASA Ames Research Center, Moffett Field, California, USA.

${ }^{7}$ Atmospheric Chemistry Division, National Center for Atmospheric Research, Boulder, Colorado, USA.
}

Copyright 2005 by the American Geophysical Union. 0148-0227/05/2004JD005172\$09.00 the interannual variability and trends of carbon monoxide (1988-1997): 1. Model formulation, evaluation, and sensitivity, submitted to Journal of Geophysical Research, 2004, hereinafter referred to as Duncan et al., submitted manuscript, 2004), as well as a minor term in the carbon cycle [Heikes et al., 2002] and in the global budgets of tropospheric ozone and $\mathrm{OH}$ [Tie et al., 2003]. Most of the observations of atmospheric methanol concentrations consist of short-term records in surface air [Heikes et al., 2002]. Recent aircraft missions have added a new dimension to our knowledge of methanol concentrations in the global troposphere [Singh et al., 2000, 2001, 2003a, 2004; Lelieveld et al., 2002]. We use here a global 3-D chemical transport model (CTM) to examine the constraints that these aircraft observations provide on current understanding of methanol sources and sinks.

[3] Global budgets of atmospheric methanol have been presented previously by Singh et al. [2000], Galbally and Kristine [2002], Heikes et al. [2002], Tie et al. [2003], and von Kuhlmann et al. [2003a, 2003b]. They are summarized in Table 1. Plant growth is the principal source. Additional 
Table 1. Global Atmospheric Budgets of Methanol Reported in the Literature

\begin{tabular}{|c|c|c|c|c|c|c|}
\hline Reference & $\begin{array}{l}\text { Singh et al. } \\
{[2000]^{\mathrm{a}}}\end{array}$ & $\begin{array}{l}\text { Heikes et al. } \\
{[2002]^{\mathrm{a}}}\end{array}$ & $\begin{array}{l}\text { Galbally and Kirstine } \\
{[2002]^{\mathrm{a}}}\end{array}$ & $\begin{array}{l}\text { Tie et al. } \\
{[2003]^{\mathrm{b}}}\end{array}$ & $\begin{array}{c}\text { von Kuhlmann et al. } \\
{[2003 \mathrm{a}, 2003 \mathrm{~b}]}\end{array}$ & This Work ${ }^{\mathrm{c}}$ \\
\hline \multicolumn{7}{|c|}{ Sources $\left(T g y r^{-1}\right)$} \\
\hline Plant growth & $75(50-125)$ & $280(50->280)$ & $100(37-212)$ & $104-312$ & 77 & $128(100-160)$ \\
\hline Plant decay & $20(10-40)$ & $20(10-40)$ & $13(5-31)$ & & & $23(5-40)$ \\
\hline Biomass burning $^{\mathrm{d}}$ & $6(3-17)$ & $12(2-32)$ & $13(6-19)$ & & 15 & $13(10-20)$ \\
\hline Urban $^{\mathrm{e}}$ & $3(2-4)$ & $8(5-11)$ & $4(3-5)$ & & 2 & $4(1-10)$ \\
\hline Atmospheric production ${ }^{\mathrm{f}}$ & $18(12-24)$ & $30(18-30)$ & $19(14-24)$ & 31 & 28 & $38^{\mathrm{g}}(50-100)$ \\
\hline Total source & $122(75-210)$ & $350(90-490)$ & $149(83-260)$ & $135-343$ & 123 & $206^{\mathrm{h}}(170-330)$ \\
\hline \multicolumn{7}{|c|}{ Sinks $\left(T g y r^{-1}\right)$} \\
\hline Gas-phase oxidation by $\mathrm{OH}$ & & $100(25-150)$ & $109(60-203)$ & $59-149$ & $77^{\mathrm{i}}$ & $129^{\mathrm{j}}$ \\
\hline In-cloud oxidation by $\mathrm{OH}(\mathrm{aq})$ & & $10(5-20)$ & $5(2-15)$ & & & $<1$ \\
\hline Dry deposition (land) & & $70(35-210)$ & $24(11-43)$ & $32-85$ & 37 & 55 \\
\hline Ocean uptake $\mathrm{k}^{\mathrm{k}}$ & & $50(-20-150)$ & $0.3(0.2-0.6)$ & & & 10 \\
\hline Wet deposition & & $10(4-36)$ & $11(5-20)$ & $16-50$ & 9 & 12 \\
\hline Total sinks & $40-50^{1}$ & $270(160-570)$ & $149(82-273)$ & $107-284$ & 123 & 206 \\
\hline Atmospheric inventory (Tg) & & 3.9 & 3.4 & $1.9-4.7$ & & 4.0 \\
\hline Atmospheric lifetime (days) & & $9(5)^{\mathrm{m}}$ & 8 & 12 & & $7(5-10)$ \\
\hline
\end{tabular}

${ }^{\mathrm{a}}$ Best estimates and ranges in parentheses.

${ }^{b}$ The authors present two budgets, one with their best estimate of the plant growth source ( $\left.312 \mathrm{Tg} \mathrm{yr}^{-1}\right)$, and one with that source reduced by a factor of 3 to match the estimate of Galbally and Kirstine [2002]. The numbers given here are the range defined by these two budgets.

${ }^{\mathrm{c}}$ Values used in the GEOS-CHEM CTM simulation presented in the text, with best estimates of ranges in parentheses. Singh et al. [2004] reported a preliminary version of this budget in their study comparing GEOS-CHEM model results to TRACE-P aircraft observations (see text)

${ }^{\mathrm{d}}$ Including biofuel use.

${ }^{\mathrm{e}}$ Including vehicles, solvent use, and manufacturing.

${ }^{\mathrm{f}}$ From reactions of $\mathrm{CH}_{3} \mathrm{O}_{2}$ with organic peroxy radicals. The self-reaction $\mathrm{CH}_{3} \mathrm{O}_{2}+\mathrm{CH}_{3} \mathrm{O}_{2}$ accounts for $85 \%$ of this source on a global basis according to our work.

${ }^{\mathrm{g}}$ Although a value of $38 \mathrm{Tg} \mathrm{yr}^{-1}$ is used in our simulation, comparison to methanol observations over the remote oceans suggests that this source is too low by a factor of two (see text). Our resulting best estimate for the range is $50-100 \mathrm{Tg}^{-1}$.

${ }^{\mathrm{h}}$ After doubling of the source from atmospheric production (see footnote $\mathrm{g}$ ), our best estimate for the total source is $240 \mathrm{Tg}^{\mathrm{yr}}{ }^{-1}$.

${ }^{\mathrm{i}}$ Von Kuhlmann et al. [2003b] give relative contributions from each sink, which we convert here to absolue values on the basis of their global source.

${ }^{\mathrm{j}}$ Including $3 \mathrm{Tg} \mathrm{yr}^{-1}$ in the stratosphere.

${ }^{\mathrm{k}}$ Net ocean uptake; the ocean is both a source and a sink of methanol [Heikes et al., 2002].

${ }^{1}$ From combined effects of gas-phase oxidation by $\mathrm{OH}$ and dry deposition (deposition velocity of $0.1 \mathrm{~cm} \mathrm{~s}^{-1}$ ).

${ }^{\mathrm{m}}$ Heikes et al. [2002] give a lifetime of 9 days in the text; however their global budget table implies a lifetime of 5 days.

sources include plant decay, biomass burning, atmospheric oxidation of methane and other volatile organic compounds (VOCs), vehicles, and industrial activities. Chemical loss by oxidation by $\mathrm{OH}$ results in an atmospheric lifetime for methanol of about 10 days. Deposition, exchange with the ocean, and heterogeneous reactions in aerosols and clouds are additional sinks but are poorly constrained.

[4] Large discrepancies are apparent between the different budgets of Table 1. Singh et al. [2000] found a factor of three imbalance between their independently estimated sources and sinks, implying a missing sink. Heikes et al. [2002] achieved closure between sources and sinks in their budget but with large uncertainties. Their estimated plant growth source is four times larger than that of Singh et al. [2000] and is partly compensated by an assumed large deposition sink. Galbally and Kirstine [2002] enforced closure by simulating methanol in a six-box global model of the atmosphere-ocean system. Tie et al. [2003] conducted global 3-D model simulations of methanol with two estimates for the plant growth source, a high value of $312 \mathrm{Tg}$ $\mathrm{yr}^{-1}$ from their bottom-up source inventory and a low value reduced by a factor of 3 to match that of Galbally and Kirstine [2002]. They presented order-of-magnitude comparisons to observations but did not conclude as to the implied constraints on the methanol budget. Von Kuhlmann et al. [2003b] evaluated a global 3-D model simulation of methanol with observations from two aircraft campaigns (SONEX and PEM-Tropics B). We present here a more detailed evaluation with a large ensemble of measurements from aircraft and ships (Figure 1).

\section{Model Description}

\subsection{General Description}

[5] We conducted a 1-year simulation of atmospheric methanol for 2001 with the GEOS-CHEM CTM v4.32 (http://www-as.harvard.edu/chemistry/trop/geos) [Bey et al., 2001]. The model is driven by GEOS-3 assimilated meteorological observations (including convective mass fluxes) from the NASA Global Modeling and Assimilation Office. The GEOS-3 data have a temporal resolution of 6 hours (3 hours for mixing depths and surface quantities), a horizontal resolution of $1^{\circ} \times 1^{\circ}$, and 48 layers in the vertical. We average them here over a $4^{\circ}$ latitude $\times$ $5^{\circ}$ longitude grid for input to GEOS-CHEM.

[6] The simulation is conducted for 18 months starting from low concentrations in July 2000. The first six months are used for initialization and we focus on the 1-year results for 2001. The methanol budget in the model is given in Table 1 and details are given below. Methanol originating from each source in Table 1 is transported as a separate species, for a total of 5 species transported in the model. The model losses of methanol are linear, so that the sum of transported species adds up to the total methanol concentration within a few percent (nonlinearity in the semiLagrangian advection algorithm prevents perfect closure). We use the model results to compare to observations not just 


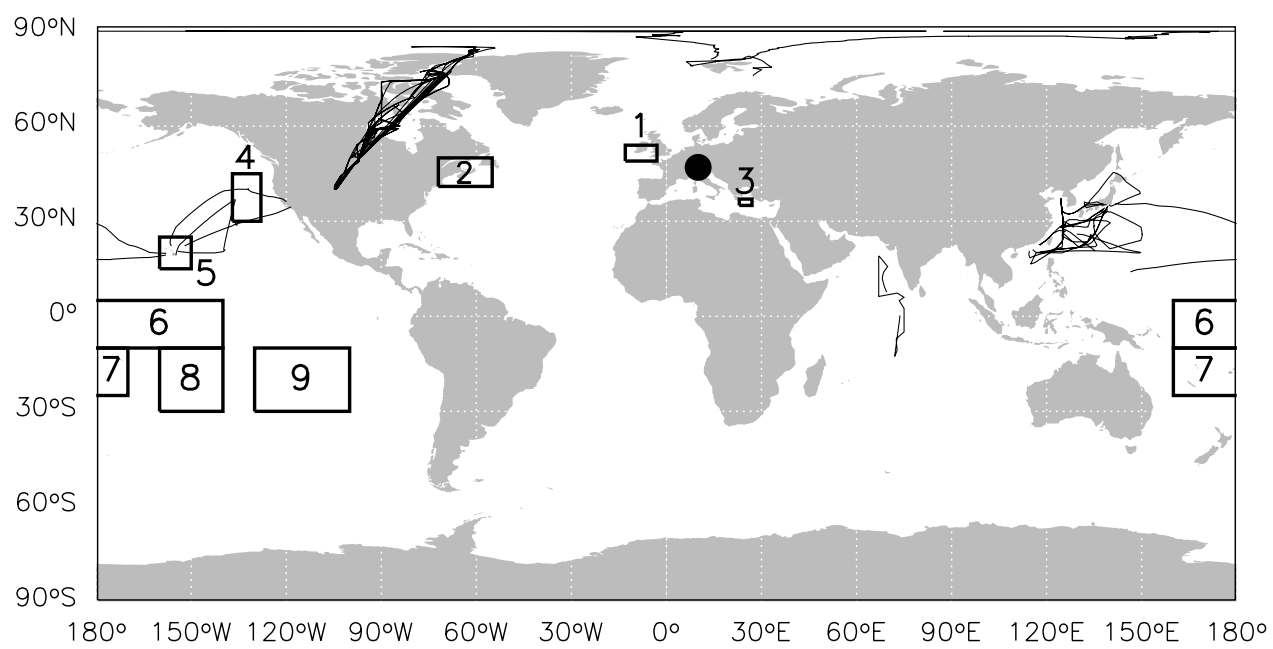

Figure 1. Atmospheric observations of methanol used for comparison with model results. Ship cruises indicated by lines include INDOEX over the Indian Ocean in March 1999 [Wisthaler et al., 2002] and AOE-2001 over the Arctic Ocean in July August 2001 (A. Hansel and A. Wisthaler, unpublished data, 2001). Aircraft missions indicated by lines include TRACE-P over the North Pacific in March-April 2001 [Singh et al., 2003a, 2004] and TOPSE over the North American Arctic in February-May 2000 (D. R. Blake, unpublished data, 2000). Additional aircraft missions indicated by boxes include SONEX over the North Atlantic in October-November 1997 (regions 1-2) [Singh et al., 2000], MINOS over the eastern Mediterranean in August 2001 (region 3) [Lelieveld et al., 2002], ITCT 2K2 over the northeast Pacific in April-May 2002 (region 4) [Nowak et al., 2004], and PEM-Tropics B over the South Pacific in February-March 1999 (regions 5-9) [Singh et al., 2001]. The symbol labeled "10" indicates the locations of Innsbruck (Austria) [Holzinger et al., 2001] and Zugspitze (Germany, $2650 \mathrm{~m}$ ASL) (A. Hansel and A. Wisthaler, unpublished data, 2003), both at (47N, 11E).

from 2001 but from other years as well, assuming that interannual variability is a relatively small source of error.

[7] Correlations of the methanol simulation with consistent simulations of $\mathrm{CO}, \mathrm{HCN}$, and acetone for 2001 are also presented for comparison with ship and aircraft observations. The $\mathrm{CO}$ and $\mathrm{HCN}$ simulations are as described by $\mathrm{Li}$ et al. [2003]. The acetone simulation is as described by Jacob et al. [2002] but without an ocean source (for reasons to be discussed in section 4.2).

\subsection{Sources of Methanol}

\subsubsection{Plant Growth}

[8] We use the plant physiology model of Galbally and Kirstine [2002] in which methanol emission scales as net primary productivity (NPP) with emission factors per unit carbon of $0.020 \%$ for grasses and $0.011 \%$ for other plants. This offers a process-based parameterization for global mapping of the methanol source from plant growth. We apply the emission factors to a monthly NPP database from the CASA 2 biosphere model with $1^{\circ} \times 1^{\circ}$ spatial resolution [Potter et al., 1993; Randerson et al., 1997]. The global NPP in that database is $17 \mathrm{Pg} \mathrm{C} \mathrm{yr}^{-1}$ for grasslands and $41 \mathrm{Pg} \mathrm{C} \mathrm{yr}{ }^{-1}$ for other plants. The resulting methanol emission is $128 \mathrm{Tg} \mathrm{yr}^{-1}$. Comparison to previous studies in Table 1 would suggest at least a factor of 2 uncertainty on this global source but our simulation of atmospheric observations implies a narrower range, as discussed later.

[9] The Galbally and Kirstine [2002] relationship of methanol emission to NPP has yet to be tested with field observations, and NPP estimates are themselves subject to substantial uncertainty [Karl et al., 2004]. Our initial simulations used monthly mean NPP values to distribute methanol emissions seasonally, but there resulted large model overestimates of observed methanol concentrations at northern midlatitudes in late summer and fall. Laboratory and field data indicate in fact that methanol emissions from young leaves are a factor of 2-3 higher than from mature leaves [McDonald and Fall, 1993; Nemecek-Marshall et al., 1995; Karl et al., 2003]. We fit these results by scaling our monthly mean NPP-based emissions with the following parameterization adapted from A. Guenther:

$$
\alpha_{i}=\beta\left(1+2 \max \left(\frac{L_{i}-L_{i-1}}{L_{i}}, 0\right)\right)
$$

where $L_{i}$ is the local leaf area index for month $i, \alpha_{\mathrm{i}}$ is the monthly scaling factor, and $\beta$ is a normalizing factor such that $\sum_{i=1}^{12} \alpha_{i}=12$ for each grid square. The normalization ensures consistency with the Galbally and Kirstine [2002] NPP-based algorithm on a yearly basis. Leaf area indices in the model are computed monthly as a function of ecosystem type, NPP, and global vegetation index (GVI), following the algorithm of Guenther et al. [1995] as implemented by Wang et al. [1998]. The resulting methanol emissions at midlatitudes peak in spring, when they may be as much as a factor of three larger than in summer. Within a given month we distribute the methanol source evenly over the daytime hours, assuming zero emission from green plants at night [Nemecek-Marshall et al., 1995; Schade and Goldstein, 2001; Warneke et al., 2002]. 


\subsubsection{Plant Decay}

[10] Warneke et al. [1999] reported the abiotic emission of methanol from decaying plant matter with an emission factor of $3-5 \times 10^{-4} \mathrm{~g}$ per $\mathrm{g}$ of $\mathrm{C}$ oxidized. We apply this emission factor to monthly mean heterotrophic respiration rates with $1^{\circ} \times 1^{\circ}$ resolution from the CASA 2 model. The global heterotrophic respiration rate is $58 \mathrm{Pg} \mathrm{C} \mathrm{yr}^{-1}$ and the resulting methanol source is $17-29 \mathrm{Tg} \mathrm{yr}^{-1}$ (best estimate $23 \mathrm{Tg} \mathrm{yr}^{-1}$ ). Galbally and Kirstine [2002] point out that part of the methanol produced by plant decay may be consumed within the litter, but they also point out that additional biotic processes contribute to the methanol source from plant decay. Their best estimate for the total source from plant decay is $13 \mathrm{Tg} \mathrm{yr}^{-1}$ (range 5-31).

\subsubsection{Biomass Burning and Biofuels}

[11] We use a methanol/CO emission factor of $0.018 \mathrm{~mol}$ $\mathrm{mol}^{-1}$ for combustion of different types of biomass, based on compilations of literature data [Yokelson et al., 1999; Andreae and Merlet, 2001]. Yokelson et al. [1999] find little variability in the emission factor between different types of fires (range 0.006-0.031 mol mol ${ }^{-1}$ ). Singh et al. [2004] find a mean emission factor of $0.016 \pm 0.002 \mathrm{~mol} \mathrm{~mol}^{-1}$ for fire plumes from Southeast Asia sampled over the NW Pacific. Christian et al. [2003] find a mean value of $0.024 \mathrm{~mol} \mathrm{~mol}^{-1}$ for Indonesian fuels. Holzinger et al. [2004] find a mean value of $0.038 \mathrm{~mol} \mathrm{~mol}^{-1}$ for aged biomass burning plumes sampled over the Mediterranean Sea, which is relatively high and which they attribute to secondary production; but the fire plumes sampled by Singh et al. [2004] were also aged.

[12] We apply the $0.018 \mathrm{~mol} \mathrm{~mol}^{-1}$ emission factor to gridded $\mathrm{CO}$ emission inventories for biomass burning (climatological, monthly) [Duncan et al., 2003] and biofuels (aseasonal) [Yevich and Logan, 2003]. Global emissions in these inventories are $440 \mathrm{Tg} \mathrm{CO} \mathrm{yr}^{-1}$ for biomass burning and $161 \mathrm{Tg} \mathrm{CO} \mathrm{yr}^{-1}$ for biofuels, and the resulting methanol sources are 9 and $4 \mathrm{Tg} \mathrm{yr}^{-1}$ respectively. Inverse modeling estimates of the global biomass burning source of $\mathrm{CO}$ constrained with surface air observations fall in the range 600-740 $\mathrm{Tg} \mathrm{CO} \mathrm{yr}^{-1}$ [Bergamaschi et al., 2000; Pétron et al., 2002], about 50\% higher than used here.

\subsubsection{Urban}

[13] We refer to "urban" as the ensemble of methanol sources from fossil fuel combustion, other vehicular emissions, solvents, and industrial activity [Galbally and Kirstine, 2002]. We use the aseasonal gridded $\left(1^{\circ} \times 1^{\circ}\right)$ EDGAR V2.0 global anthropogenic emission inventory for 1990, which gives a total urban alkanol emission of 8.2 $\mathrm{Tg} \mathrm{yr}^{-1}$ [Olivier et al., 1994], and assume that methanol accounts for half of this total or $4.1 \mathrm{Tg} \mathrm{yr}^{-1}$. Goldan et al. [1995] reported a concentration ratio of methanol to nitrogen oxides $\left(\mathrm{NO}_{\mathrm{x}}\right)$ of $0.17 \mathrm{~mol} \mathrm{~mol}^{-1}$ in urban air in Colorado in winter; scaling of this source to a global fossil fuel combustion $\mathrm{NO}_{\mathrm{x}}$ source of $23 \mathrm{Tg} \mathrm{N} \mathrm{yr}^{-1}$ would yield an anthropogenic source of methanol of $9.1 \mathrm{Tg} \mathrm{yr}^{-1}$. Aircraft measurements by J. deGouw (unpublished) indicate methanol/CO enhancement ratios of $0.050 \mathrm{~mol} \mathrm{~mol}^{-1}$ in Denver but $0.011-0.014 \mathrm{~mol} \mathrm{~mol}^{-1}$ in other U.S. cities. An emission ratio of $0.013 \mathrm{~mol} \mathrm{~mol}^{-1}$, combined with a global fossil fuel source of CO of $480 \mathrm{Tg} \mathrm{yr}^{-1}$ (Duncan et al., submitted manuscript, 2004), would imply a global methanol

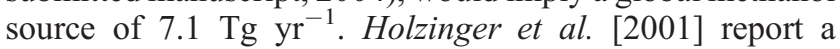

methanol:benzene enhancement ratio of $0.8 \mathrm{~mol} \mathrm{~mol}^{-1}$ for urban air in Innsbruck, Austria. The EDGAR V2.0 inventory gives a global benzene emission of $1.2 \mathrm{Tg} \mathrm{yr}^{-1}$ from vehicles and industry, which would imply a methanol source of only $0.4 \mathrm{Tg} \mathrm{yr}^{-1}$. The urban source of methanol is thus highly uncertain but is clearly small on a global scale.

\subsubsection{Atmospheric Production}

[14] Methanol is produced in the atmosphere by reactions of the methylperoxy $\left(\mathrm{CH}_{3} \mathrm{O}_{2}\right)$ radical with itself and with higher organic peroxy $\left(\mathrm{RO}_{2}\right)$ radicals [Madronich and Calvert, 1990; Tyndall et al., 2001]:

$$
\begin{gathered}
\mathrm{CH}_{3} \mathrm{O}_{2}+\mathrm{CH}_{3} \mathrm{O}_{2} \rightarrow \mathrm{CH}_{3} \mathrm{OH}+\mathrm{CH}_{2} \mathrm{O}+\mathrm{O}_{2} \\
\mathrm{CH}_{3} \mathrm{O}_{2}+\mathrm{RO}_{2} \rightarrow \mathrm{CH}_{3} \mathrm{OH}+\mathrm{R}^{\prime} \mathrm{CHO}+\mathrm{O}_{2}
\end{gathered}
$$

Alternate branches for these reactions, not producing methanol, are

$$
\begin{gathered}
\mathrm{CH}_{3} \mathrm{O}_{2}+\mathrm{CH}_{3} \mathrm{O}_{2} \rightarrow \mathrm{CH}_{3} \mathrm{O}+\mathrm{CH}_{3} \mathrm{O}+\mathrm{O}_{2} \\
\mathrm{CH}_{3} \mathrm{O}_{2}+\mathrm{RO}_{2} \rightarrow \mathrm{CH}_{3} \mathrm{O}+\mathrm{RO}+\mathrm{O}_{2}
\end{gathered}
$$

The $\mathrm{CH}_{3} \mathrm{O}_{2}$ and $\mathrm{RO}_{2}$ radicals are produced in the atmosphere by oxidation of VOCs. The sum of reactions (R1), (R1'), (R2), and (R2') typically accounts for less than $10 \%$ of the $\mathrm{CH}_{3} \mathrm{O}_{2}$ sink in current chemical mechanisms. The dominant atmospheric sinks are the reactions with $\mathrm{HO}_{2}$ and NO, which do not produce methanol:

$$
\begin{gathered}
\mathrm{CH}_{3} \mathrm{O}_{2}+\mathrm{HO}_{2} \rightarrow \mathrm{CH}_{3} \mathrm{OOH}+\mathrm{O}_{2} \\
\mathrm{CH}_{3} \mathrm{O}_{2}+\mathrm{NO} \rightarrow \mathrm{CH}_{3} \mathrm{O}+\mathrm{NO}_{2}
\end{gathered}
$$

[15] We calculate the atmospheric source of methanol from (R1) and (R2) with a GEOS-CHEM simulation of tropospheric ozone- $\mathrm{NO}_{\mathrm{x}}$-VOC chemistry [Fiore et al., 2003]. Primary VOCs in that simulation include methane, ethane, propane, higher alkanes, $>\mathrm{C}_{2}$ alkenes, isoprene, acetone, and methanol. The simulation uses recommended data from Tyndall et al. [2001] for the kinetics and methanol yields of (R1), and also for (R3) involving the acetonylperoxy radical $\left(\mathrm{CH}_{3} \mathrm{C}(\mathrm{O}) \mathrm{CH}_{3} \mathrm{O}_{2}\right)$ produced by oxidation of acetone. The methanol yields at $298 \mathrm{~K}$ for these two reactions are 0.63 and 0.5 , respectively. We assume a 0.5 yield for all other $\mathrm{CH}_{3} \mathrm{O}_{2}+\mathrm{RO}_{2}$ reactions, following Madronich and Calvert [1990]. The resulting global source of methanol is $38 \mathrm{Tg} \mathrm{yr}^{-1}$. Reaction (R1) contributes $85 \%$ of that global total. The remaining $15 \%$, contributed by (R2), mainly involves $\mathrm{RO}_{2}$ radicals produced from biogenic isoprene and is largely confined to the continental boundary layer, where it is much smaller than the primary emission from plant growth. In the remote atmosphere, where the atmospheric production of methanol is of most interest, the $\mathrm{CH}_{3} \mathrm{O}_{2}$ radicals driving (R1) originate mainly from the oxidation of methane.

[16] Previous literature estimates of the atmospheric source of methanol from (R1) and (R2), similarly obtained with global tropospheric chemistry models, are in the range 
18-31 $\mathrm{Tg}^{-1}$ (Table 1), lower than our estimate. These include $30 \mathrm{Tg} \mathrm{yr}^{-1}$ from Heikes et al. [2002] computed with an earlier version of GEOS-CHEM. Discrepancies between estimates reflect differences in the abundances of $\mathrm{NO}$ and $\mathrm{HO}_{2}$, the $\mathrm{CH}_{3} \mathrm{O}_{2}$ reaction rate constants, the yield of methanol from (R1) and (R2), and the importance of (R2). Uncertainties in the (R1) rate constant and in the corresponding methanol yield are each about $30 \%$ at $298 \mathrm{~K}$ [Tyndall et al., 2001] and higher at colder temperatures. As we will see, observations from the PEM-Tropics B aircraft mission over the South Pacific suggest an even larger atmospheric source of methanol than is used here.

\subsection{Sinks of Methanol}

\subsubsection{Gas-Phase Oxidation by $\mathrm{OH}$}

[17] We use the rate constant $k=3.6 \times 10^{-12} \exp [-415 / T]$ $\mathrm{cm}^{3}$ molecule $\mathrm{s}^{-1}$ recommended by Jimenez et al. [2003] with an uncertainty of $20 \%$. We apply this rate constant to a 3-D archive of monthly mean $\mathrm{OH}$ concentrations from the Fiore et al. [2003] GEOS-CHEM simulation of tropospheric ozone- $\mathrm{NO}_{\mathrm{x}}$-VOC chemistry. The lifetime of methylchloroform against tropospheric oxidation by $\mathrm{OH}$ (proxy for the global mean tropospheric $\mathrm{OH}$ concentration) is 5.6 years in that simulation [Martin et al., 2003]. This is within the range constrained by the methylchloroform observations, which imply a $25 \%$ uncertainty in global mean $\mathrm{OH}$ concentrations [Intergovernmental Panel on Climate Change (IPCC), 2001]. Stratospheric loss of methanol is computed using $\mathrm{OH}$ concentrations archived from a global 2-D stratospheric chemistry model [Schneider et al., 2000] and amounts to only $2 \%$ of the loss in the troposphere. Our computed lifetime of methanol against oxidation by $\mathrm{OH}$ is 11 days. Addition of errors in quadrature implies an uncertainty of $30 \%$ on this value.

\subsubsection{Aqueous-Phase Oxidation by $\mathrm{OH}(\mathrm{aq})$}

[18] Methanol dissolves in aqueous aerosols (Henry's law constant $\left.H=1.6 \times 10^{-5} \exp [4900 / T] \mathrm{M} \mathrm{atm}^{-1}\right)$ and can then be oxidized by $\mathrm{OH}(\mathrm{aq})\left(k=1.0 \times 10^{9} \exp [-590 / T]\right.$ $\mathrm{M}^{-1} \mathrm{~s}^{-1}$; Elliot and McCracken [1989]). The corresponding first-order loss rate constant $\left(\mathrm{s}^{-1}\right)$ for atmospheric methanol is $k^{\prime}=H L R T k[\mathrm{OH}(\mathrm{aq})]$ where $L$ is the dimensionless liquid water content, $R$ is the gas constant, and $[\mathrm{OH}(\mathrm{aq})]$ is the $\mathrm{OH}(\mathrm{aq})$ concentration in units of $\mathrm{M}$ (moles per liter of water). The reaction takes place mainly in clouds, where $L$ is more than 3 orders of magnitude higher than in a clearsky atmosphere. The GEOS-3 meteorological archive provides 3 -D cloud optical depths $\tau$ from which we estimate $L=$ $4 \tau r / 3 Q \Delta Z$ where $r$ is the effective cloud droplet radius (taken to be $10 \mu \mathrm{m}), Q \approx 2$ is the cloud droplet extinction efficiency, and $\Delta Z$ is the vertical thickness of the gridbox. The $\mathrm{OH}(\mathrm{aq})$ concentration in cloud droplets is largely determined by aqueous-phase cycling with $\mathrm{HO}_{2}(\mathrm{aq}) / \mathrm{O}_{2}^{-}$and depends in a complicated way on cloud composition [Jacob, 1986]. We assume here a simple parameterization $[\mathrm{OH}(\mathrm{aq})]=\delta[\mathrm{OH}(\mathrm{g})]$ where $[\mathrm{OH}(\mathrm{g})]$ is the gas-phase concentration calculated in GEOS-CHEM without consideration of aqueous-phase cloud chemistry, and $\delta=1 \times 10^{-19} \mathrm{M} \mathrm{cm}^{3}$ molecule ${ }^{-1}$ is chosen to fit the cloud chemistry model results of Jacob [1986]. The resulting lifetime of methanol against in-cloud oxidation by $\mathrm{OH}(\mathrm{aq})$ is longer than 1 year. Heikes et al. [2002] and Galbally and Kirstine [2002] found a larger role for incloud oxidation by $\mathrm{OH}(\mathrm{aq})$ in their global methanol budgets, amounting to $5-10 \%$ of the gas-phase loss (Table 1). Their assumed $\mathrm{OH}(\mathrm{aq})$ concentrations and aqueous-phase $\mathrm{CH}_{3} \mathrm{OH}+\mathrm{OH}$ rate constants are higher than ours.

[19] A few studies have raised the possibility of a missing heterogeneous sink for methanol in aerosols or clouds. Singh et al. [2000] suggested that such a sink might explain their observed decrease of methanol concentrations from the middle to upper troposphere at northern midlatitudes (SONEX aircraft mission). Jaeglé et al. [2000] found that unexpectedly high formaldehyde concentrations measured in the upper troposphere during SONEX correlated with methanol, and speculated that reactive uptake of methanol in cirrus clouds with a reaction probability $\gamma=0.01$ could provide an explanation. Yokelson et al. [2003] observed the depletion of methanol in a cloud polluted by biomass burning smoke, and Tabazadeh et al. [2004] proposed that surface reactions of methanol on cloud droplets could be responsible. However, statistical comparison of in-cloud versus clear-sky methanol concentrations in the large data set from the TRACE-P aircraft mission indicates no significant differences at any altitude [Singh et al., 2004]. Upper tropospheric observations from the SONEX mission indicate no depletion in air processed by deep convection or cirrus clouds [Jaeglé et al., 2000]. Laboratory studies indicate no significant reactive uptake of methanol by sulfuric acid aerosols [Iraci et al., 2002], ice [Hudson et al., 2002; Winkler et al., 2002], or mineral oxide surfaces [Carlos-Cuellar et al., 2003]. Kane and Leu [2001] report fast reaction of methanol with sulfuric acid in concentrated solutions but Iraci et al. [2002] attribute this result to an experimental artifact. At present, the weight of evidence does not support a fast heterogeneous sink for methanol.

\subsubsection{Deposition to Land}

[20] Microbial and foliar uptake of methanol by vegetation and soils is difficult to separate from the plant growth and decay sources, either observationally or for model purposes. Investigators have placed soil and leaf litter [Schade and Goldstein, 2001] and foliage [NemecekMarshall et al., 1995] in enclosures and observed a net emission of methanol. However, these studies used enclosures that were flushed with methanol-free air. Recent measurements by A. Guenther (unpublished) indicate that there can be a net uptake of methanol when enclosures are flushed with air containing ambient levels of methanol.

[21] Measurement of the diurnal cycle of methanol concentrations at continental surface sites provides some separation of microbial uptake from plant growth emission, which is restricted to daytime. Kesselmeier et al. [2002] observed no significant diurnal variation at a site in the Amazon forest, but other observations at sites in the tropics and northern midlatitudes indicate decreases over the course of the night ranging from about 30\% [Goldan et al., 1995] to several-fold [Riemer et al., 1998; Holzinger et al., 2001; Karl et al., 2004], suggesting surface uptake. A 30\% decrease over the course of an 8-hour summer night, and for a typical nighttime mixing depth of $100 \mathrm{~m}$, would imply a methanol deposition velocity of $0.12 \mathrm{~cm} \mathrm{~s}^{-1}$. Karl et al. [2004] measured methanol deposition to a tropical forest ecosystem by using a combination of eddy covariance and vertical gradients, and found a mean methanol deposition 
velocity of $0.27 \pm 0.14 \mathrm{~cm} \mathrm{~s}^{-1}$. On the basis of the above information, and acknowledging the large uncertainty, we assume here a constant dry deposition velocity of $0.2 \mathrm{~cm} \mathrm{~s}^{-1}$ to land. We assume that this deposition velocity also applies to ice-covered surfaces since Boudries et al. [2002] found that Arctic snow is a net sink for methanol. The resulting atmospheric lifetime of methanol against dry deposition is 26 days. Including a methanol sink from dry deposition improves significantly the ability of the model to reproduce observations at northern midlatitudes in fall and winter.

\subsubsection{Wet Deposition}

[22] We simulate wet deposition of methanol with the GEOS-CHEM wet deposition scheme described by Liu et al. [2001]. This scheme accounts for scavenging of watersoluble species by convective updrafts, convective anvils, and large-scale precipitation. The scavenging coefficients used by Liu et al. [2001] are scaled here to the dissolved fraction of methanol inferred from the local liquid water content and Henry's law constant. Scavenging is assumed to take place in warm clouds only $(T>268 \mathrm{~K})$. The retention efficiency of methanol upon cloud droplet freezing is taken to be 0.02 , by analogy with previous assumptions for $\mathrm{CH}_{3} \mathrm{OOH}$ and $\mathrm{CH}_{2} \mathrm{O}$ [Mari et al., 2000], so that scavenging is inefficient in mixed liquid-ice clouds where the precipitation involves riming. Laboratory studies indicate that methanol coverage of ice surfaces is low, less than $10^{-4}$ of a monolayer at equilibrium [Hudson et al., 2002; Winkler et al., 2002], supporting the assumption of a low retention efficiency. The resulting lifetime of methanol against wet deposition is 120 days. With such a long lifetime, wet deposition does not significantly affect the vertical profile of methanol in the troposphere [Crutzen and Lawrence, 2000].

\subsubsection{Uptake by the Ocean}

[23] Simple solubility considerations imply that the ocean mixed layer must be a large reservoir for methanol [Galbally and Kirstine, 2002; Singh et al., 2003a]. Heikes et al. [2002] point out that methanol is both produced and consumed in the ocean. Singh et al. [2003a] observed a gradient of increasing methanol concentrations from the marine boundary layer to the free troposphere over the remote North Pacific during TRACE-P, implying an ocean sink with a mean deposition velocity of $0.08 \mathrm{~cm} \mathrm{~s}^{-1}$. Measurements taken at the Mace Head coastal site in Ireland also show evidence of methanol uptake by the ocean, with a similar deposition velocity [Carpenter et al., 2004]. Our GEOS-CHEM results presented in the work of Singh et al. [2003a] show that an ocean saturation ratio of $90 \%$ for methanol, combined with a standard two-layer parameterization of ocean-atmosphere exchange, gives a good simulation of the observed TRACE-P vertical gradients. In the absence of better information we assume that the $90 \%$ saturation ratio holds globally. The resulting lifetime of methanol against net uptake by the ocean is 130 days.

\section{Global Model Budget and Atmospheric Distribution of Methanol}

[24] Table 1 summarizes our global model budget of

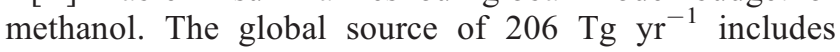
contributions from plant growth $(62 \%)$, atmospheric oxidation of VOCs $(18 \%)$, plant decay $(11 \%)$, biomass burning and biofuels $(6 \%)$, and vehicles and industrial activities
(2\%). The global sink balancing that source is dominated by gas-phase oxidation by $\mathrm{OH}(63 \%)$ with minor contributions from dry deposition to land $(26 \%)$, wet deposition $(6 \%)$, net uptake by the ocean (5\%), and aqueous-phase oxidation in clouds $(<1 \%)$. The resulting atmospheric lifetime of methanol is 7 days and the global atmospheric burden is $4.0 \mathrm{Tg}$. A preliminary version of our model budget was presented by Singh et al. [2004] in a study comparing GEOS-CHEM results to their TRACE-P aircraft observations (reference to our budget is given there as B. D. Field et al., manuscript in preparation, 2003). That preliminary version did not include deposition of methanol to land or the dependence of methanol emissions on leaf age.

[25] Our global source of methanol is in the range of previous literature cited in Table $1\left(122-350 \mathrm{Tg} \mathrm{yr}^{-1}\right)$. Differences reflect principally the magnitude of the plant growth source. Our value for that source $\left(128 \mathrm{Tg} \mathrm{yr}^{-1}\right)$ is close to that of Galbally and Kirstine [2002] (100 $\left.\mathrm{Tg} \mathrm{yr}^{-1}\right)$, as would be expected since we followed their algorithm. Our atmospheric source of methanol from $\mathrm{CH}_{3} \mathrm{O}_{2}$ reactions $\left(38 \mathrm{Tg} \mathrm{yr}^{-1}\right)$ is larger than previous estimates $(18-31 \mathrm{Tg}$ $\left.\mathrm{yr}^{-1}\right)$.

[26] Gas-phase oxidation by $\mathrm{OH}$ is a major methanol sink in all the inventories of Table 1. However, the principal methanol sink in the Heikes et al. [2002] budget is dry deposition to land and oceans, with an assumed deposition velocity of $0.4 \mathrm{~cm} \mathrm{~s}^{-1}$. As mentioned above, the TRACE-P aircraft data of Singh et al. [2003a] imply a much lower deposition velocity to the ocean. Fast deposition to land in the Heikes et al. [2002] budget (90 $\mathrm{Tg}^{-1}{ }^{-1}$ ) partly compensates for their high terrestrial biogenic source $(280 \mathrm{Tg}$ $\left.\mathrm{yr}^{-1}\right)$. The relative contributions to the methanol sink from gas-phase oxidation by $\mathrm{OH}$, dry deposition, and wet deposition in our model are essentially the same as in the previous global 3-D model study by von Kuhlmann et al. [2003a] $(63 \%, 30 \%$, and 7\% respectively). That study did not report separate deposition terms to land and ocean.

[27] Figure 2 shows the mean concentrations of methanol simulated by the model in surface air and at $500 \mathrm{hPa}$, for January and July. Surface air concentrations over land exceed 5-10 ppbv in the tropics and at northern midlatitudes in summer. The particularly high concentrations over Siberia in July are due to the long continental fetch and the late emergence of leaves. Surface air concentrations at northern midlatitudes in winter drop to $0.5-2 \mathrm{ppbv}$. Concentrations over land decrease typically by a factor of $2-5$ from the surface to $500 \mathrm{hPa}$, reflecting the surface source and the 7-day lifetime. There is by contrast little vertical gradient over the oceans. Concentrations over the northern hemisphere oceans $(0.5-1 \mathrm{ppbv})$ show little seasonal variation, because faster chemical loss in summer balances the effect of the larger continental source. Concentrations over the southern hemisphere oceans are higher in winter $(0.5-1 \mathrm{ppbv})$ than in summer $(0.2-0.5 \mathrm{ppbv})$ since the continental source in the southern hemisphere is mainly in the tropics and has little seasonal variation. Concentrations are lowest (below $0.2 \mathrm{ppbv}$ ) in surface air over Antarctica in summer.

\section{Evaluation With Observations}

[28] We examine in this section how the above estimates of methanol sources and sinks, when implemented in a 
January surface

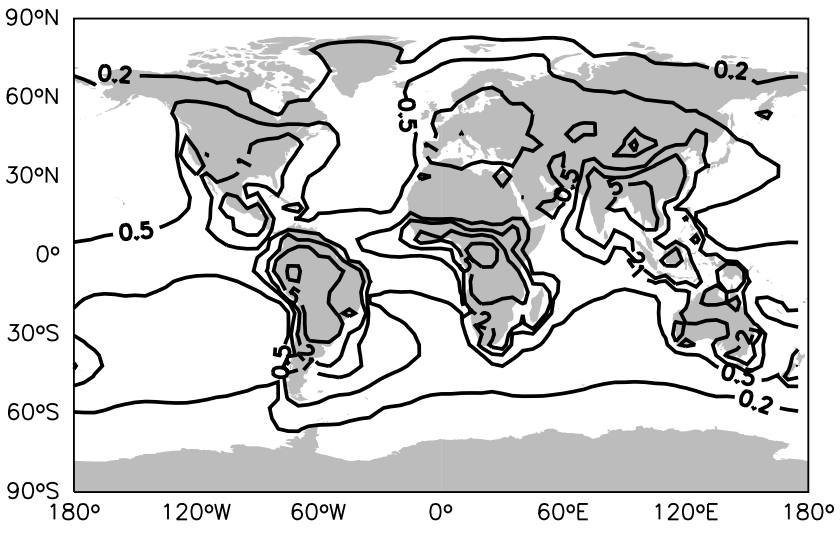

January $500 \mathrm{hPa}$

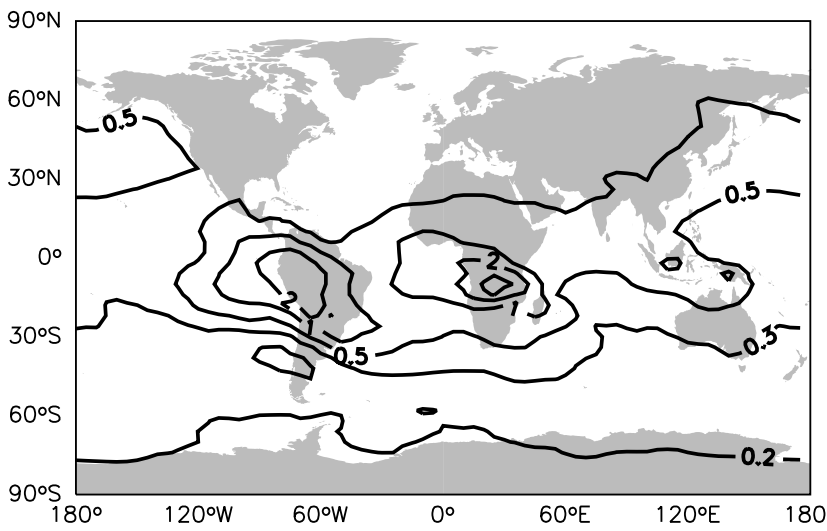

July surface

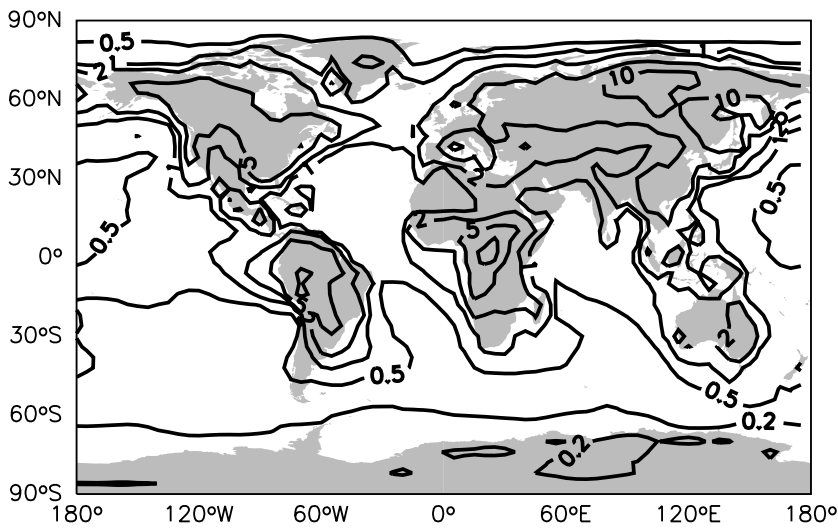

July $500 \mathrm{hPa}$

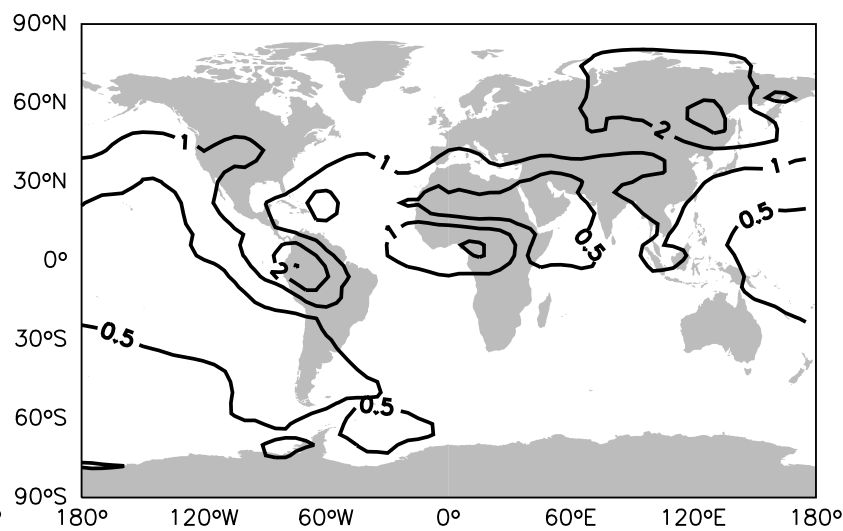

Figure 2. Simulated monthly mean concentrations of methanol (ppbv) in surface air and at $500 \mathrm{hPa}$ for January and July 2001.

global CTM, succeed in reproducing the observed atmospheric concentrations of methanol. Our primary focus is on observations from aircraft and ships, which integrate source information over large regions. Observations from surface continental sites, reviewed by Heikes et al. [2002], are few and show high spatial variability that we cannot expect to reproduce given our crude model representation of sources. We use these surface observations mainly to examine largescale features, including seasonal variations and tropical concentrations, that are of particular interest for testing the model.

\subsection{Surface Concentrations}

[29] The review of Heikes et al. [2002] gives representative surface air concentrations of 20 (range $0.03-47$ ) ppbv in urban air, $10(1-37)$ ppbv over forests, 6 (4-9) ppbv over grasslands, 2 (1-4) ppbv for continental background, and $0.9(0.3-1.4)$ ppbv over the northern hemispheric oceans. Our model values are roughly consistent with these ranges, as shown in Figure 2. Urban air is not resolved on the scale of the model.

[30] The Heikes et al. [2002] compilation includes no surface data for tropical land ecosystems, where the model predicts high concentrations year-round. Measurements by Kesselmeier et al. [2002] in the Rondônia tropical forest of Brazil (10S, 63W) for a 7-day period in October 1999 (end of dry season) indicate a range of 1 to 6 ppbv. Our mean simulated concentration for that site and month is much higher, $10 \mathrm{ppbv}$, with dominant contributions from plant growth (6 ppbv), plant decay ( 2 ppbv), and biomass burning (2 ppbv). Measurements by Karl et al. [2004] at a tropical forest site in Costa Rica $(10 \mathrm{~N}, 84 \mathrm{~W})$ for a 20 -day period in April-May 2003 (peak of dry season) indicate a mean concentration of $2.2 \mathrm{ppbv}$. Our mean simulated concentration for that site and 2-month period is $2.1 \mathrm{pppbv}$, in agreement with observations, with a major contribution from plant growth (1.2 ppbv) and minor contributions of about 0.3 ppbv each from plant decay, biomass burning, and atmospheric production. The lower model value in Costa Rica than in Rondônia reflects the shorter continental fetch. The model shows little seasonal variation at the Rondonia site (monthly means range from 8 to $10 \mathrm{ppbv}$ ) but more at the Costa Rica site (1.2 to $2.7 \mathrm{ppbv}$ ). At the latter site, the seasonal maximum is in the wet season (June-October) when the plant growth source is high, and the seasonal minimum is in the early dry season (January-February) before biomass burning. Karl et al. [2004] also made methanol flux measurements at the Costa Rica site, which indicate a value $50 \%$ higher than the parameterization of Galbally and Kristine [2002] when normalized to the estimated tropical forest NPP. On the other hand, the data from Kesselmeier et al. [2002] would suggest that the NPPbased parameterization of Galbally and Kristine [2002] is too high for the Amazon forest. More observations of 


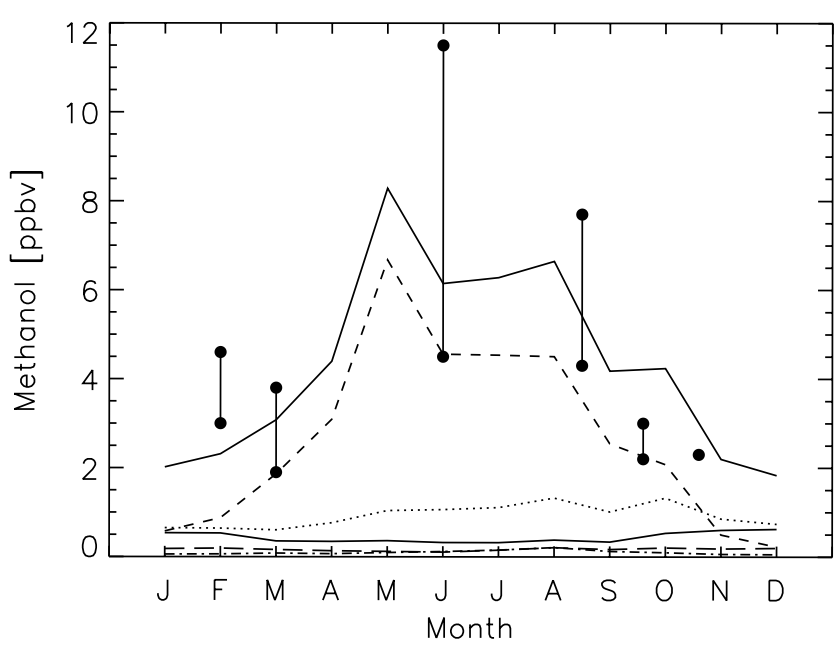

Figure 3. Seasonal variation of methanol concentrations at Innsbruck, Austria. The ranges of observations reported by Holzinger et al. [2001] for different times of year in 19961997 are shown as vertical lines with symbols. These observations are for the non-urban component of methanol, after subtraction of the urban component based on correlation with benzene. Model results are shown as the solid line, with additional lines identifying contributions from individual sources in the model: plant growth (short dashes), plant decay (dots), urban (thin solid), biomass burning and biofuels (long dashes), and atmospheric production (dash-dot). methanol concentrations and fluxes are clearly needed for tropical land ecosystems.

[31] To our knowledge, the only methanol observations in the literature extending over a full yearly cycle are those of Holzinger et al. [2001] taken in the outskirts of Innsbruck, Austria $(47 \mathrm{~N}, 11 \mathrm{E})$. These authors used concurrent measurements of benzene (emitted by vehicles) to separate the local urban from the regional nonurban components of methanol. Figure 3 shows the observed ranges for the nonurban component. There is a spring-summer maximum and fall-winter minimum, reflecting biogenic emission. Concentrations drop by more than a factor of 2 from June to September. Also shown in Figure 3 are the simulated methanol concentrations and the contributions from the individual model sources. Plant growth is the main model source except in winter, when plant decay and urban sources become relatively important. The model reproduces the seasonal variation in the observations, including the rise from winter to spring and the decrease from spring to fall. The latter reflects in the model the weaker emission from mature leaves.

[32] Ship measurements from Wisthaler et al. [2002] over the Indian Ocean during INDOEX 1999 (March 1999) provide another important data set for methanol in surface air. The cruise track extended from $20 \mathrm{~N}$ to $12 \mathrm{~S}$, starting from the west coast of India and extending south of the intertropical convergence zone (Figure 1). Observed methanol concentrations exceed $1 \mathrm{ppbv}$ in Indian outflow and drop to $0.5-0.6 \mathrm{ppbv}$ in southern hemispheric air. Wisthaler et al. [2002] reported a strong correlation of methanol with $\mathrm{CO}$, which we compare in Figure 4 to our mean monthly model results for 2001 sampled along the cruise track. The agreement is remarkably good. The model captures the

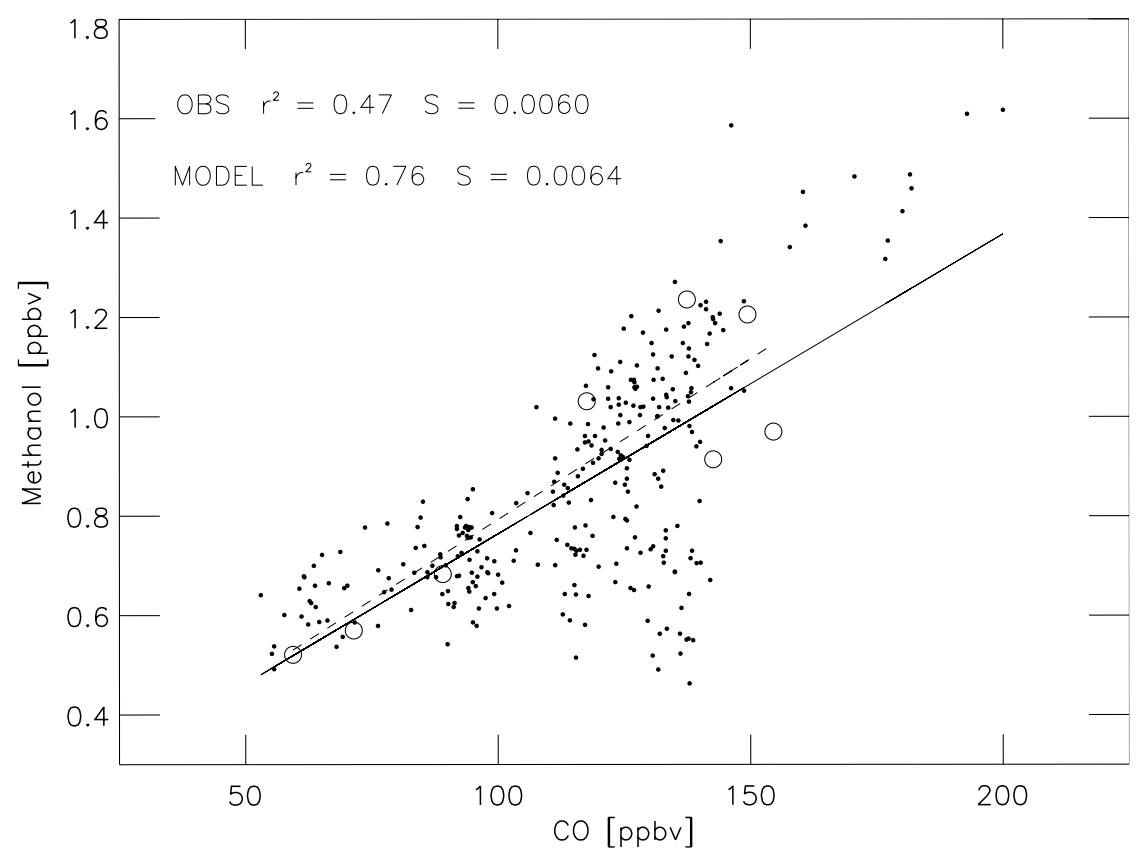

Figure 4. Methanol-CO correlations along the INDOEX 1999 cruise track over the Indian Ocean (Figure 1). Observations from Wisthaler et al. [2002] are shown as small dots, with linear regression as solid line. Monthly mean GEOS-CHEM results along the cruise track are shown as large open circles, with linear regression as dashed line. Coefficients of determination $\left(r^{2}\right)$ and slopes of the linear regressions $(S)$ are shown inset. 

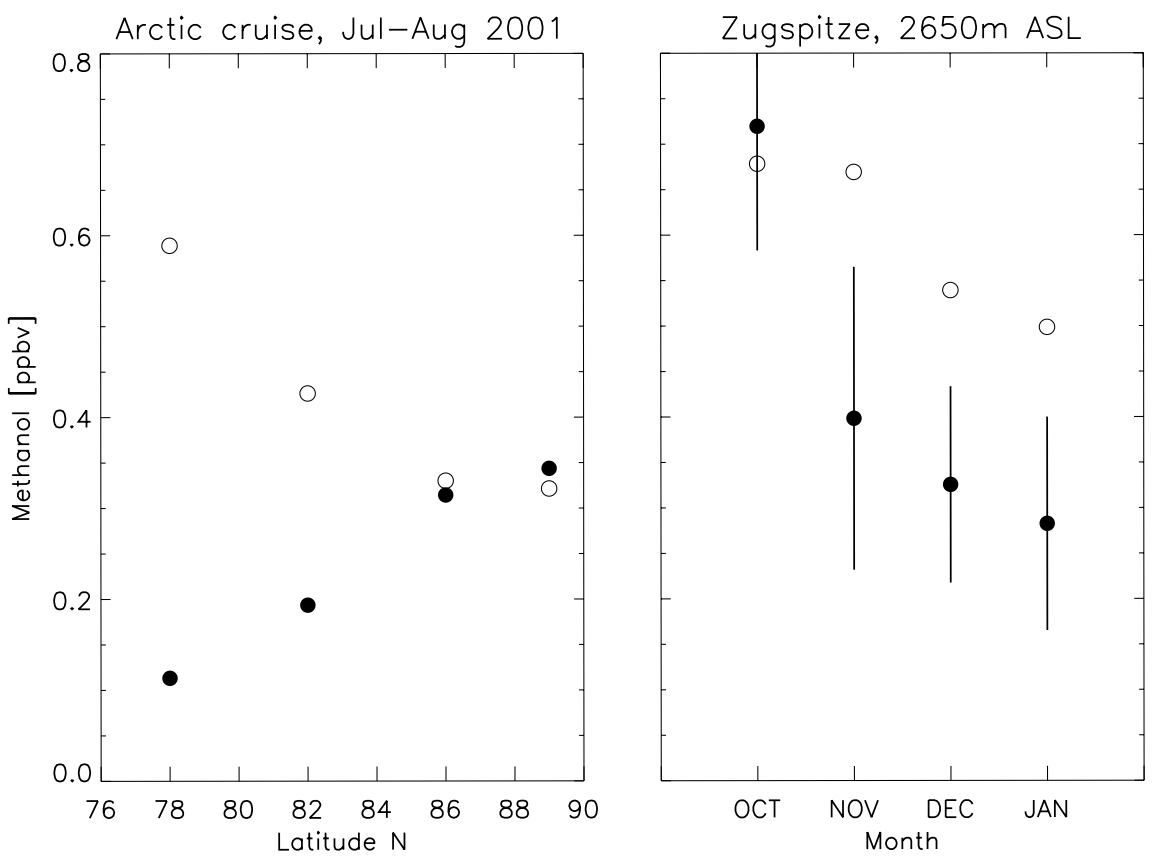

Figure 5. Mean methanol concentrations from the AOE-2001 Arctic cruise in July August 2001 as a function of latitude and from Zugspitze (southern Germany, $2650 \mathrm{~m}$ ASL) in October 2002 to January 2003 as a function of month. Unpublished observations from A. Wisthaler and A. Hansel (closed circles) are compared to model results (open circles). Standard deviations on the observations are shown for Zugspitze.

clean $0.5-0.6$ ppbv background and the observed relationship with $\mathrm{CO}$, although it does not capture the population of observations with relatively high $\mathrm{CO}$ but low methanol (hence the stronger methanol-CO correlation in the model, $r^{2}=0.76$ versus $\left.r^{2}=0.47\right)$. Over India in the model the methanol is mostly from plant growth, while CO is mostly from combustion; the methanol-CO correlation in Indian outflow reflects varying degrees of dilution with the marine background rather than a commonality of methanol and $\mathrm{CO}$ source processes.

[33] Additional unpublished methanol measurements have been made by A. Wisthaler and A. Hansel on a ship cruise in the Arctic in July August 2001 (AOE-2001), and at Zugspitze in southern Germany (47N, 11E, $2650 \mathrm{~m}$ altitude) for four months in October 2002 to January 2003. These are shown in Figure 5 together with the corresponding model results. The model reproduces the low Arctic cruise observations north of $85 \mathrm{~N}(0.30-0.35 \mathrm{ppbv})$, reflecting deposition to the ocean, but not the even lower concentrations (0.1-0.2 ppbv) observed further south; these low concentrations are from only a few measurements and suggest a strong local ocean sink. Observations at Zugspitze show a decrease from $0.7 \mathrm{ppbv}$ in October to $0.3 \mathrm{ppbv}$ in January. The model also shows a decrease, mostly from the deposition sink, but not as strong as observed. This would suggest a nonphotochemical sink of methanol missing from the model. However, the TOPSE aircraft observations over the North American Arctic in winter, to be discussed in section 4.3, show higher concentrations than at Zugspitze and do not suggest such a missing sink.

\subsection{Asian Outflow (TRACE-P Mission)}

[34] The TRACE-P aircraft mission in March-April 2001 provided extensive data for methanol and other species in
Asian outflow over the North Pacific [Jacob et al., 2003]. The outflow included a major contribution from seasonal biomass burning in Southeast Asia [Heald et al., 2003a]. Flight tracks are shown in Figure 1. Our model simulation is for the same meteorological year as TRACE-P. We sample the model along the flight tracks and for the flight days for comparison to observations. GEOS-CHEM simulations for the TRACE-P period have been evaluated previously with observations for a number of species including in particular CO [Kiley et al., 2003; Palmer et al., 2003b] and HCN [Li et al., 2003], which we discuss below in the context of their correlations with methanol. The model gives a good simulation of Asian outflow pathways with no evident transport bias [Liu et al., 2003; I. Bey et al., Characterization of transport errors in chemical forecasts from a global tropospheric chemical transport model, submitted to Journal of Geophysical Research, 2005]. Simulation of the $\mathrm{CO}_{2}$ observations indicates a $45 \%$ underestimate of the net biospheric carbon emission for China in the CASA 2 model during the TRACE-P period [Suntharalingam et al., 2004]. However, as we will see below, there is no evident bias in our methanol simulation.

\subsubsection{Vertical Profiles}

[35] Figure 6 compares the mean simulated and observed vertical profiles of methanol concentrations for the four TRACE-P quadrants separated at $30 \mathrm{~N}, 150 \mathrm{E}$. The four quadrants contrast fresh Asian outflow west of $150 \mathrm{E}$ to more background North Pacific air to the east.

[36] The observed methanol concentrations in the NW quadrant decrease from $1.5-2 \mathrm{ppbv}$ in the boundary layer to $0.9-1.3 \mathrm{ppbv}$ in the free troposphere, rise again to a maximum in excess of $2 \mathrm{ppbv}$ in the upper troposphere, and then decline to $0.1 \mathrm{ppbv}$ above the tropopause at $12 \mathrm{~km}$. 


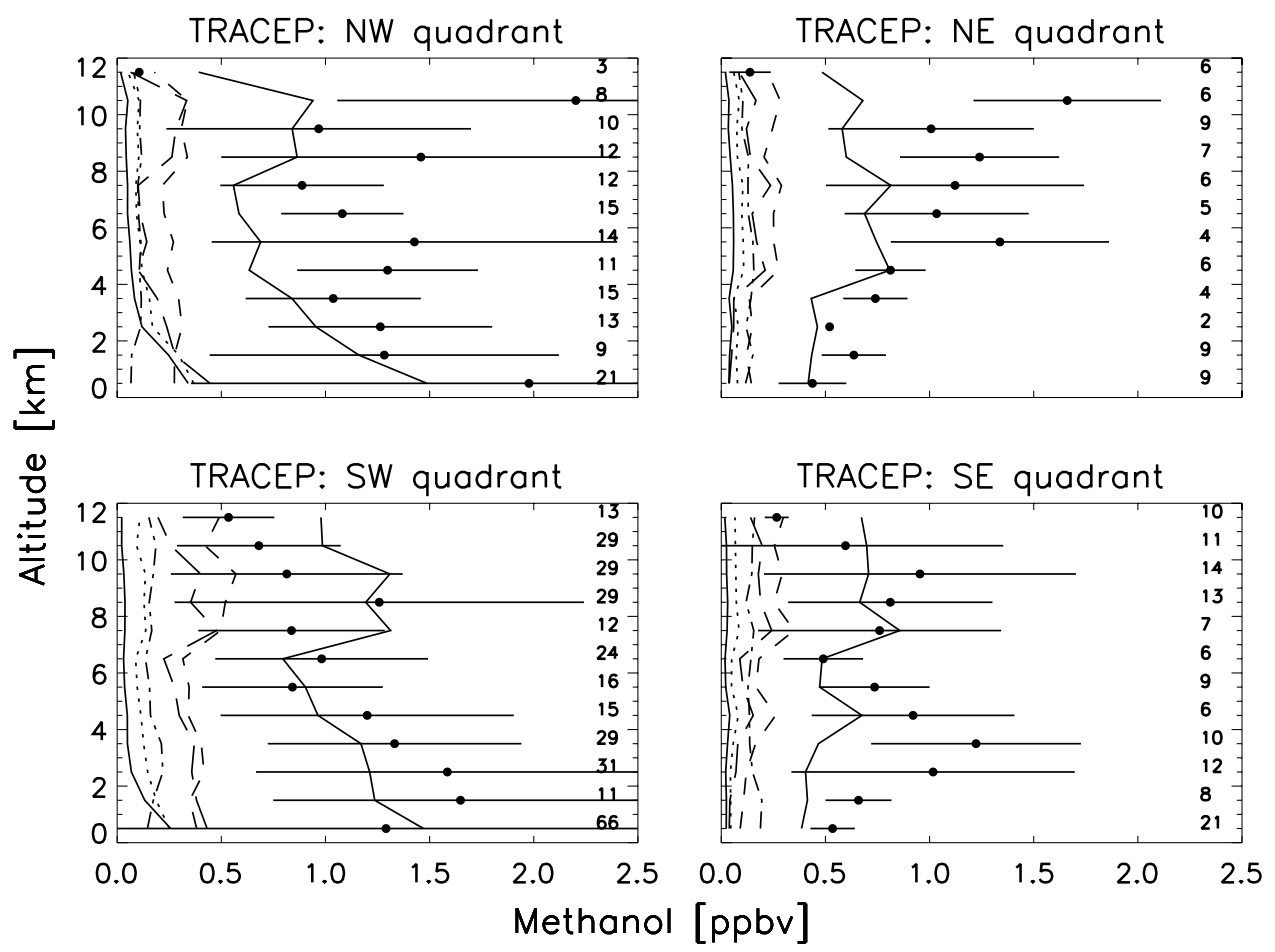

Figure 6. Vertical profiles of methanol concentrations from the TRACE-P aircraft mission over the North Pacific (March-April 2001) averaged over four quadrants separated at 30N, 150E (Figure 1). Means and standard deviations of observations are shown as symbols and horizontal lines; the number of observations contributing to each average is indicated. Model results are shown as solid lines, with additional lines identifying contributions from individual model sources: plant growth (short dashes), plant decay (dots), urban (thin solid), biomass burning and biofuels (long dashes), and atmospheric production (dash-dot).

The model reproduces these features although it is up to a factor 2 too low in the middle troposphere. Stratospheric concentrations cannot be compared because of excessive stratosphere-troposphere exchange in the GEOS assimilated meteorological data used to drive the model [Liu et al., 2001; Tan et al., 2004]. The plant growth source in the model contributes a relatively featureless background of 0.3 ppbv throughout the troposphere in this NW quadrant. The boundary layer enhancement reflects a mix of Chinese emissions from plant decay, biofuels, and urban sources. The upper tropospheric enhancement is due to outflow from deep convection in Southeast Asia and is contributed mainly by the plant growth and biomass burning components.

[37] The observed mean profile for the SW quadrant in Figure 6 shows greater influence from Southeast Asia than the NW quadrant. Concentrations decrease gradually with altitude, from $1.5 \mathrm{ppbv}$ in the boundary layer to $0.5-1 \mathrm{ppbv}$ in the middle and upper troposphere but with a convective enhancement apparent at 8-9 $\mathrm{km}$. The model reproduces this structure with no evident bias.

[38] Observations in the NE quadrant show a marked increase with altitude, in contrast to the western quadrants. Asian influence is principally in the middle and upper troposphere. The model underestimates this Asian influence, by about the same factor as for the free tropospheric Asian outflow in the NW quadrant. The relatively low methanol concentrations in the lower troposphere, both in the model and in the observations, reflect gas-phase oxida- tion and ocean uptake of methanol as the Asian air masses subside [Singh et al., 2003a].

[39] Asian influence during TRACE-P was weakest in the SE quadrant, which lies south of the dominant outflow track. The observed layer of high methanol concentrations at $2-4 \mathrm{~km}$ altitude is from one single Hawaii-Guam flight where the aircraft sampled repeatedly an Asian outflow plume that had traveled southward and subsided [Crawford et al., 2004]. High CO concentrations (200 ppbv) were observed in that layer. Previous analysis of the GEOSCHEM CO simulation shows that this layer is displaced upward and diluted in the model relative to the observations [Heald et al., 2003b]. A similar bias is found for methanol, as the model enhancement is at $4-5 \mathrm{~km}$ altitude and peaks at only 0.7 ppbv. The model is also low in the marine boundary layer $(0.4 \mathrm{ppbv}$, versus $0.6 \mathrm{ppbv}$ in the observations); atmospheric production is the most important model source there and is probably too weak, as discussed later in the context of the PEM-Tropics B observations over the South Pacific.

[40] Singh et al. [2004] previously compared results from our preliminary model version (not including dry deposition to land or the decrease in the plant growth source as leaves age) to their mean observed background vertical profile of methanol concentrations for the ensemble of the mission. This showed agreement within $10 \%$ up to $6 \mathrm{~km}$ altitude, but a growing model overestimate at higher altitudes (up to a factor of 3 at $11 \mathrm{~km}$ ) that they speculated could reflect heterogeneous chemical loss not captured by the model. In 

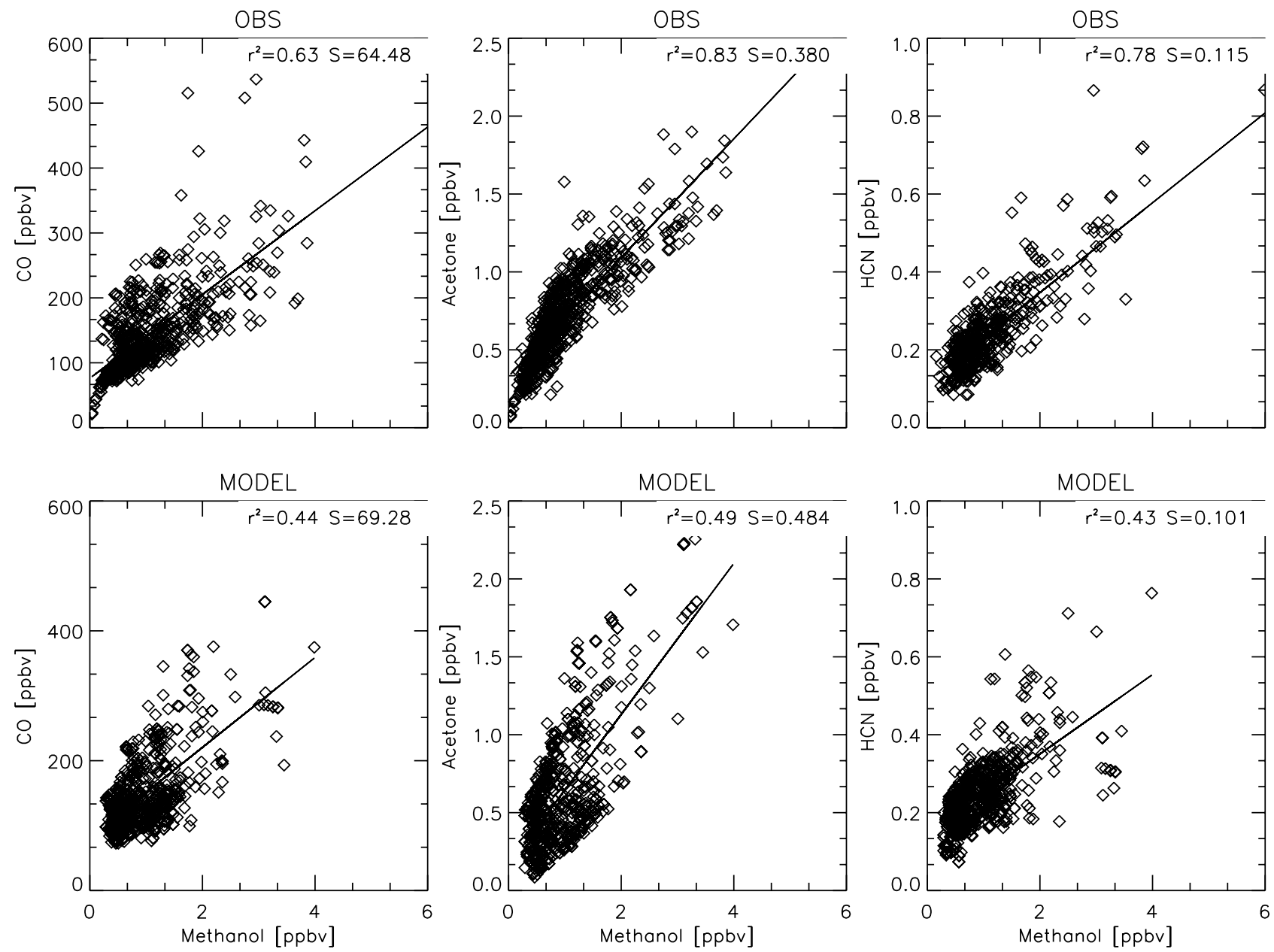

Figure 7. Correlations of methanol with $\mathrm{CO}$, acetone, and $\mathrm{HCN}$ concentrations in the ensemble of TRACE-P data. Observations (top panels) are compared to model results (bottom panels). Coefficients of determination $\left(r^{2}\right)$, regression lines, and corresponding slopes $(S)$ are indicated.

the Singh et al. [2004] comparison, observed methanol concentrations decrease from $0.8 \mathrm{ppbv}$ at $6 \mathrm{~km}$ to $0.35 \mathrm{ppbv}$ at $11 \mathrm{~km}$ (filtered against stratospheric influence); whereas model values increase from $0.9 \mathrm{ppbv}$ at $6 \mathrm{~km}$ to $1.1 \mathrm{ppbv}$ at $11 \mathrm{~km}$. Our comparisons in Figure 6 do not show such a model bias in the upper troposphere, but instead considerable regional difference in simulated and observed vertical profiles for the different quadrants, as discussed above. The decreasing trend from 6 to $11 \mathrm{~km}$ in the observations is found only for the southern quadrants. In addition, the model values presented here are lower than in the preliminary simulation reported by Singh et al. [2004] due to our subsequent inclusion of a land deposition sink in the model. This affects in particular the simulation of upper tropospheric concentrations, which include a major contribution from convective outflow of tropical continental air.

\subsubsection{Correlations With Other Species}

[41] Further insight can be gained by examining the observed correlations of methanol with other species. In the ensemble of TRACE-P observations we find that methanol correlates most strongly with acetone $\left(\mathrm{r}^{2}=0.83\right.$, slope $\left.=0.38 \mathrm{~mol} \mathrm{~mol}^{-1}\right), \mathrm{HCN}\left(\mathrm{r}^{2}=0.78\right.$, slope $=0.12 \mathrm{~mol}$ $\left.\mathrm{mol}^{-1}\right)$, and CO $\left(\mathrm{r}^{2}=0.63\right.$, slope $\left.=64 \mathrm{~mol} \mathrm{~mol}^{-1}\right)$. These correlations are shown in Figure 7 . The slopes are given with methanol as denominator. We generated corresponding correlations from the model results sampled along the flight tracks. These are also shown in Figure 7. The CO and HCN simulations are as described in the work of Li et al. [2003]. The acetone simulation presented here is that of Jacob et al. [2002] applied to the TRACE-P period, but without an ocean source since the TRACE-P observations indicate that the ocean was in fact a net sink for acetone [Singh et al., 2003a]. We find that an ocean source for acetone in the model would destroy the correlation with methanol since the ocean is a sink for methanol.

[42] The model reproduces the correlation between methanol and acetone found in the observations $\left(\mathrm{r}^{2}=0.49\right.$, slope $=0.48 \mathrm{~mol} \mathrm{~mol}^{-1}$ in the model). The biogenic acetone source in the model is scaled to isoprene emission [Jacob et al., 2002], while that of methanol is scaled to NPP. The stronger correlation in the observations suggests that the sources of acetone and methanol are governed by more similar processes than is assumed in the model. Measurements at rural U.S. sites in summer have previously shown a strong correlation between acetone and methanol with an acetone/methanol slope of $0.21-0.27 \mathrm{~mol} \mathrm{~mol}^{-1}$ [Goldan et al., 1995; Riemer et al., 1998]. The higher slope observed here is due to anthropogenic sources of acetone. 

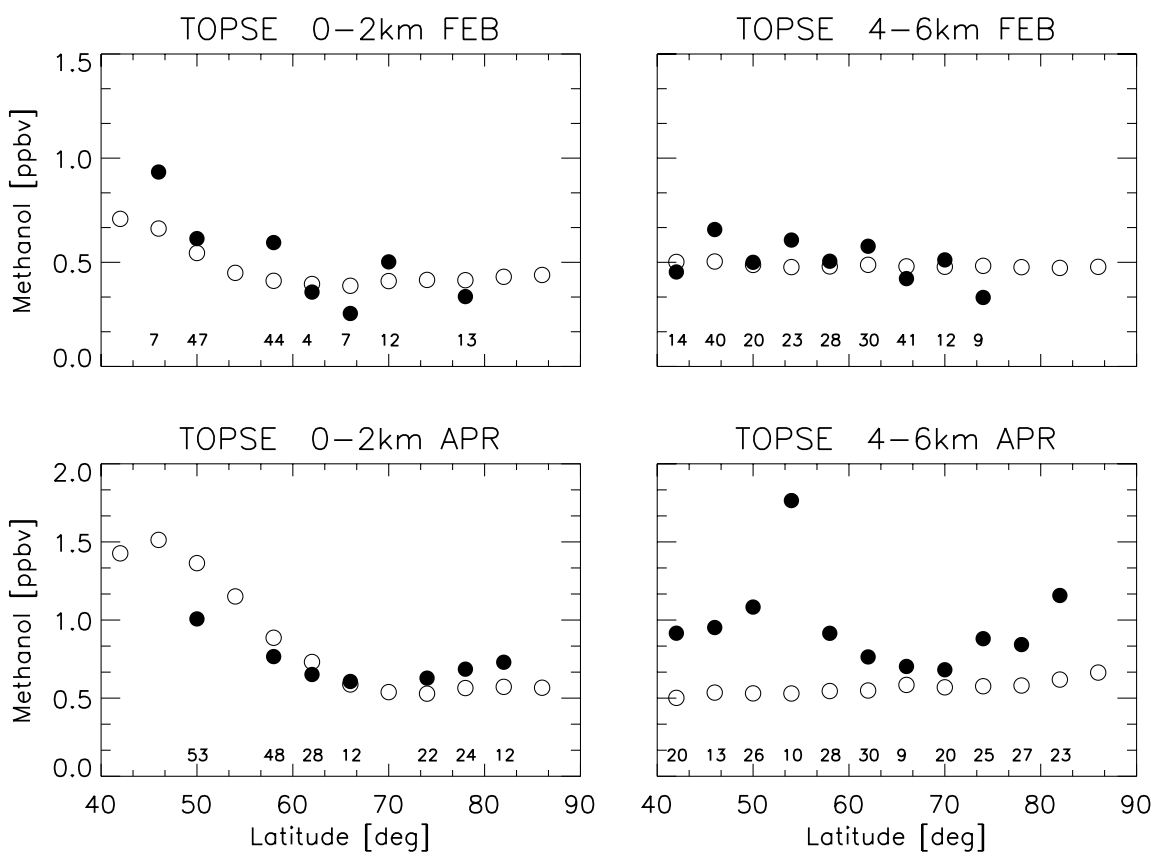

Figure 8. Latitudinal profiles of methanol concentrations at North American high latitudes during the TOPSE mission (Figure 1), for February and April and for 0-2 and 4-6 km altitude. Mean observations (D. R. Blake, unpublished data, 2000) are shown as solid circles; the number of observations used to compute the mean is also shown. Model results are shown as open circles.

[43] The observed correlation between methanol and $\mathrm{HCN}$ is well simulated by the model $\left(\mathrm{r}^{2}=0.43\right.$, slope $=$ $0.10 \mathrm{~mol} \mathrm{~mol}^{-1}$ ). The dominant source of $\mathrm{HCN}$ variability in the TRACE-P data is biomass burning in Southeast Asia [Li et al., 2003; Singh et al., 2003b]. The observed HCN/ $\mathrm{CO}$ molar emission ratio from biomass burning varies in the literature over a large range from $0.03 \%$ to $1.1 \%$, with a best fit for the TRACE-P conditions of $0.27 \%$ [Li et al., 2003]. Combined with our estimated methanol/CO molar emission ratio from biomass burning of $1.8 \% \mathrm{~mol} \mathrm{~mol}^{-1}$ this yields an $\mathrm{HCN} /$ methanol emission ratio of $0.15 \mathrm{~mol} \mathrm{~mol}^{-1}$. The weaker slope in the model and in the observations likely reflects biogenic methanol emissions in Southeast Asia that are collocated with the biomass burning emissions.

[44] Good agreement between model and observations is also found in the correlation of methanol with $\mathrm{CO}\left(\mathrm{r}^{2}=\right.$ 0.44 , slope $=69 \mathrm{~mol} \mathrm{~mol}^{-1}$ in the model). CO here serves as a general tracer of Asian outflow and the correlation mainly provides support for the overall magnitude of methanol export from the Asian continent. Although the model underestimates the TRACE-P methanol observations in the middle troposphere (Figure 6), the methanol-CO correlation is principally driven by strong outflow events in the boundary layer [Liu et al., 2003].

\subsection{Other Aircraft Observations}

[45] We now compare model results to methanol observations from other aircraft missions including TOPSE at North American high latitudes in February-May 2000 (D.R. Blake, unpublished data), SONEX over the North Atlantic in October-November 1997 [Singh et al., 2000], MINOS over the eastern Mediterranean in August 2001 [Lelieveld et al., 2002], ITCT 2K2 over the Northeast Pacific in April-May 2002 [Nowak et al., 2004], and
PEM-Tropics B over the South Pacific in February-March 1999 [Singh et al., 2001]. Aside from MINOS, these missions were conducted for years other than the 2001 model year. We use monthly mean vertical profiles in the model over the flight regions (Figure 1) to compare to the mean observations. The measurements in TRACE-P, SONEX, and PEM-Tropics B were made by real-time gas chromatography (GC). The measurements in ITCT $2 \mathrm{~K} 2$ and MINOS were made by proton transfer mass spectrometry (PTR-MS). A ship-based intercomparison of online PTRMS and real-time GC-MS methods indicates high correlation between the two and agreement within a few percent [de Gouw et al., 2003]. Calibration differences of up to $20 \%$ may be expected between the GC measurements of Singh et al. from different missions. The TOPSE measurements were made by GC analysis from collected air canisters, all with the same relative humidity and the same lapse of time between collection and analysis. The accuracy is estimated to be $30 \%$ and the precision is much better.

[46] Additional aircraft methanol data are available from the PEM-West B mission over the NW Pacific in FebruaryMarch 1994 [Singh et al., 1995] and from the LBACLAIRE mission over the rain forest in Surinam in March 1998 [Williams et al., 2001]. The PEM-West B data are from the same region and season as TRACE-P, and show similar concentrations [Singh et al., 2004], but represent a much sparser data set. The LBA-CLAIRE data indicate low methanol concentrations, averaging $1.1 \mathrm{ppbv}$ in the boundary layer and $0.6 \mathrm{ppbv}$ in the free troposphere. These would suggest, consistent with Kesselmeier et al. [2002], that methanol emission from tropical forests of South America is much lower than predicted from the Galbally and Kirstine [2002] parameterization. However, quantitative comparison to the model is difficult because the observations were taken 

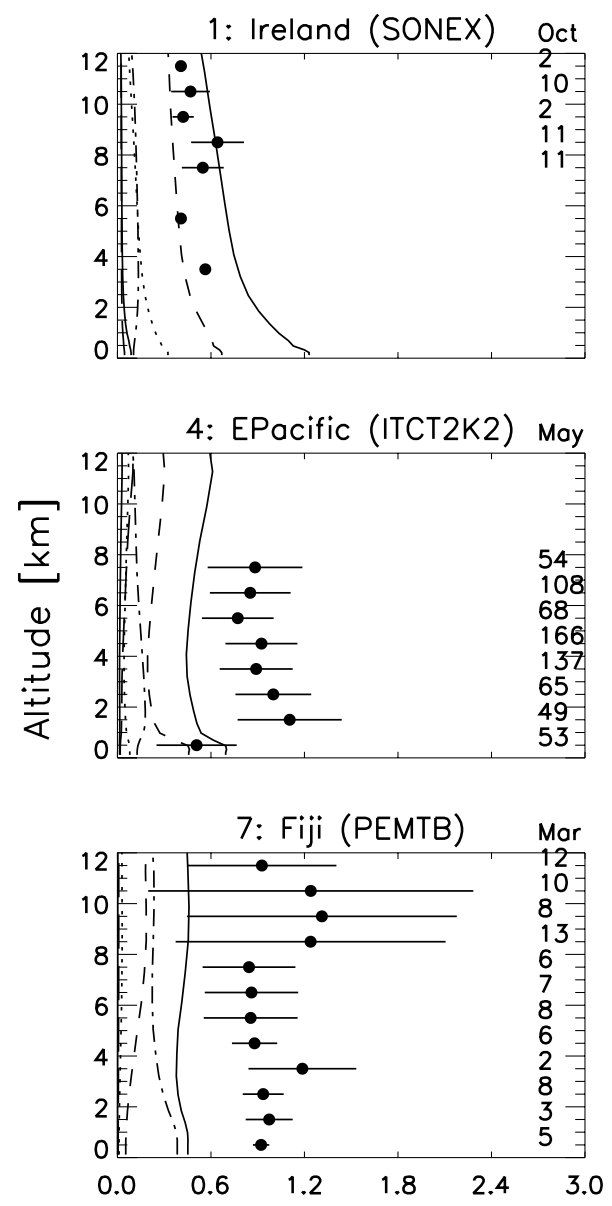
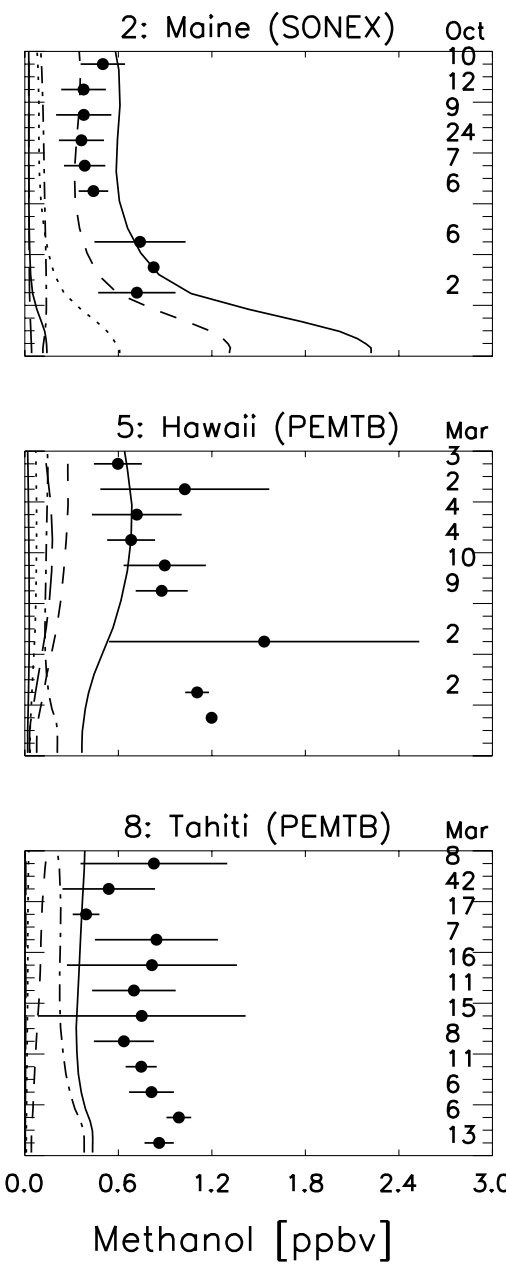
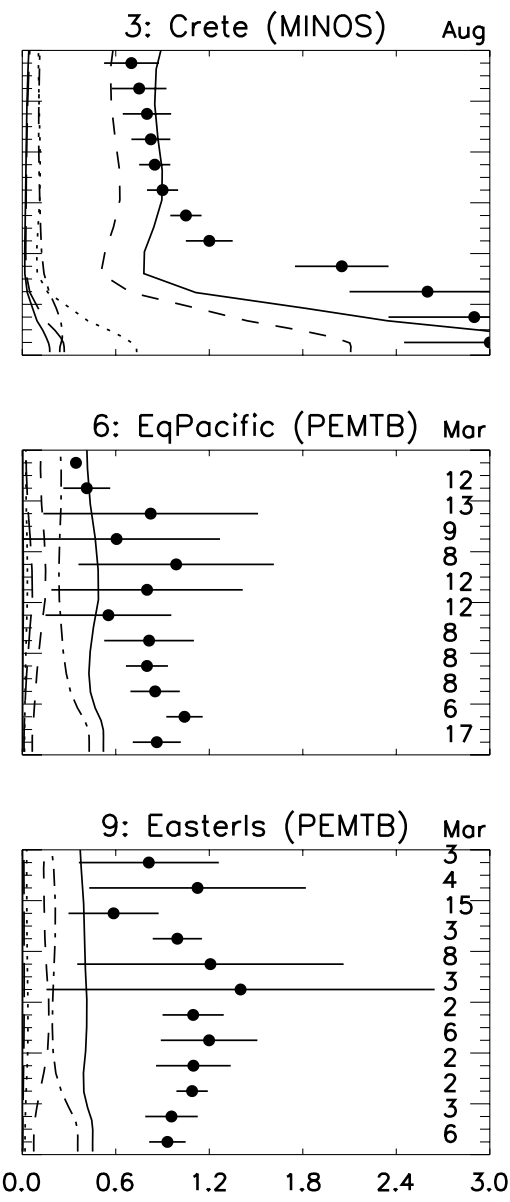

Figure 9. Vertical profiles of methanol concentrations from the SONEX, MINOS, ITCT 2K2, and PEM-Tropics B aircraft missions averaged over the regions of Figure 2. Symbols and lines are as for Figure 6. The MINOS observations are taken from Lelieveld et al. [2002] without information on the number of observations.

under conditions of marine inflow and only about 12 hours downwind of the coast.

[47] The TOPSE measurements are of particular interest as they characterize the latitudinal gradient at high northern latitudes during the transition from winter to spring [Atlas et al., 2003]. We show in Figure 8 the latitudinal profiles measured at $0-2$ and $4-6 \mathrm{~km}$ altitude in February and April (only a few observations are available in May). Also shown are the corresponding model profiles, sampled as monthly means along the TOPSE flight tracks. Boundary layer concentrations in February show a latitudinal decrease from $1 \mathrm{ppbv}$ at northern midlatitudes to $0.4 \mathrm{ppbv}$ in the Arctic, both in the model and the observations, due to the shutting down of the biogenic source and the effect of surface deposition. The same latitudinal gradient is found in April but concentrations are about $0.2 \mathrm{ppbv}$ higher, similarly in the model and in the observations, reflecting the springtime source. Concentrations at $4-6 \mathrm{~km}$ altitude show by contrast little latitudinal gradient, which the model explains as reflecting a weaker influence of the dry deposition sink. The February observations at $4-6 \mathrm{~km}(0.5 \mathrm{ppbv})$ are higher than the wintertime Zugspitze observations discussed in section 4.1 and are more consistent with the model results.
The model misses the observed April enhancement at 4$6 \mathrm{~km}$ south of $60 \mathrm{~N}$ although it captures it in the $0-2 \mathrm{~km}$ data; this could be due to model error in the springtime onset of the source. We have no explanation for the high concentrations (above $1 \mathrm{ppbv}$ ) observed north of $80 \mathrm{~N}$ at $4-$ $6 \mathrm{~km}$ in April.

[48] Aircraft observations at northern midlatitudes are available from the SONEX, MINOS, and ITCT 2K2 missions. These are shown in Figure 9 together with the corresponding model results. Observed concentrations in the middle and upper troposphere in SONEX are low, $0.4 \mathrm{ppbv}$ on average, and this is reproduced in the model with only a slight positive bias. Reduced methanol emission from mature leaves is critical for simulation of the SONEX observations; without this reduction the simulated methanol concentrations would be much higher in fall because of the weak photochemical sink. The global 3-D model study of von Kuhlmann et al. [2003b] also found good agreement with the SONEX observations using a global methanol source $40 \%$ lower than ours (Table 1 ). They did not account for the decrease of methanol emission with leaf age.

[49] The model reproduces the free tropospheric concentrations observed in MINOS (0.6-1 ppbv) over the Medi- 
terranean in July, and also the high values in surface air. It is too low in the lower free troposphere $(2-4 \mathrm{~km})$, possibly reflecting difficulties in simulating vertical mixing and transport over this highly heterogeneous region. Salisbury et al. [2003] observed a mean concentration of $3.3 \mathrm{ppbv}$ at a site in Crete during MINOS, and as shown in Figure 9 this is consistent with model results. Comparisons to the von Kuhlmann et al. [2003a, 2003b] model presented in that paper found it to be too low by a factor of four on average, possibly reflecting its low plant growth source.

[50] Observations from the ITCT $2 \mathrm{~K} 2$ campaign off the California coast in April-May average 0.9-1.1 ppbv in the $1-7 \mathrm{~km}$ column with lower values near the surface, consistent with an ocean sink. The model is $0.2-0.6 \mathrm{ppbv}$ too low. The comparison near the surface is subject to uncertainty because of land-ocean contrast (the model has more continental influence than the observations, but this may be due to numerical diffusion). The free tropospheric observations in ITCT $2 \mathrm{~K} 2$ are similar in magnitude to the TRACE-P observations for the northeast quadrant (Figure 6), but the model shows lower values in ITCT $2 \mathrm{~K} 2$ because of the longer distance from the Asian continent. Atmospheric production makes a relatively large contribution $(0.2 \mathrm{ppbv})$ to the simulated concentrations in ITCT $2 \mathrm{~K} 2$, reflecting the strong radiation and low $\mathrm{NO}_{\mathrm{x}}$ concentrations over the subsiding northeast Pacific. A possibility, discussed further below, is that this atmospheric source in the model is too weak.

[51] Observations from the PEM-Tropics B campaign over the South Pacific are typically $0.6-1.2 \mathrm{ppbv}$ with little horizontal or vertical structure (Figure 9). These values are remarkably high considering the remoteness from land. The model is about a factor of 2 too low, averaging about $0.4-0.5 \mathrm{ppbv}$ with little structure. A unique feature of model results for this region is that atmospheric production is the dominant source, contributing $0.2-0.4 \mathrm{ppbv}$. This source is favored by the high UV radiation (stimulating $\mathrm{CH}_{3} \mathrm{O}_{2}$ production), low $\mathrm{NO}_{\mathrm{x}}$ concentrations (suppressing competition from the $\mathrm{CH}_{3} \mathrm{O}_{2}+\mathrm{NO}$ reaction), and low $\mathrm{CO} / \mathrm{CH}_{4}$ ratio (resulting in a high $\mathrm{CH}_{3} \mathrm{O}_{2} / \mathrm{HO}_{2}$ ratio). The model underestimate in this region suggests that atmospheric production in the model is too low. A doubling of this source would largely correct the discrepancy and would be consistent with the featureless character of the observations.

[52] We previously discussed in section 2 the uncertainties in computing the atmospheric source of methanol from $\mathrm{CH}_{3} \mathrm{O}_{2}$ reactions. Examination of model results for the PEM-Tropics (B) region indicates that self-reaction (R1) accounts for $5-10 \%$ of the $\mathrm{CH}_{3} \mathrm{O}_{2}$ sink, reaction (R4) with $\mathrm{NO}$ for $20 \%$, and reaction (R3) with $\mathrm{HO}_{2}$ for the rest; reaction (R2) is negligible. $\mathrm{CH}_{3} \mathrm{OOH}$ produced by (R3) has an atmospheric lifetime of about a day against losses by reaction with $\mathrm{OH}$ and photolysis:

(R5a) $\quad \mathrm{CH}_{3} \mathrm{OOH}+\mathrm{OH} \rightarrow \mathrm{CH}_{3} \mathrm{O}_{2}+\mathrm{H}_{2} \mathrm{O}$

(R5b) $\quad \mathrm{CH}_{3} \mathrm{OOH}+\mathrm{OH} \rightarrow \mathrm{CH}_{2} \mathrm{O}+\mathrm{OH}+\mathrm{H}_{2} \mathrm{O}$

$$
\mathrm{CH}_{3} \mathrm{OOH}+\mathrm{h} \nu \rightarrow \mathrm{CH}_{3} \mathrm{O}+\mathrm{OH}
$$

[53] Reaction ( $\mathrm{R} 5 \mathrm{a}$ ) recycles $\mathrm{CH}_{3} \mathrm{O}_{2}$ while reactions (R5b) and (R6) do not. For typical atmospheric conditions, (R5a) accounts for about $50 \%$ of $\mathrm{CH}_{3} \mathrm{OOH}$ loss and (R5b) and (R6) each for about 25\%. Assuming chemical steady state for $\mathrm{CH}_{3} \mathrm{OOH}$, the effective sink of $\mathrm{CH}_{3} \mathrm{O}_{2}$ from (R3) is determined by $k_{3}(1-f)$, where the $\mathrm{CH}_{3} \mathrm{O}_{2}$ recycling efficiency $f=k_{5 a} /\left(k_{5 a}+k_{5 b}+k_{6}\right)$ is about $50 \%$. Jet Propulsion Laboratory (JPL) [2003] gives uncertainty estimates of $30 \%$ for $k_{3}, 40 \%$ for $k_{5}$, and $50 \%$ for $k_{6}$ (it gives no uncertainty estimate for the recommended branching ratio $70 / 30$ for $\left.k_{5 a} / k_{5 b}\right)$. Thus the overall uncertainty on the effective $\mathrm{CH}_{3} \mathrm{O}_{2}$ sink from (R3) could be a factor of two. In addition, Martin et al. [2002] showed that the NO concentrations simulated by GEOS-CHEM over the South Pacific are about 50\% higher than the PEM-Tropics (B) observations. Combination of these two factors could easily allow a doubling of the source of methanol from (R1), considering that this source is quadratic in the $\mathrm{CH}_{3} \mathrm{O}_{2}$ concentration. Photochemical model calculations by Olson et al. [2001] along the PEM-Tropics (B) flight tracks indicated a $50 \%$ overestimate of observed $\mathrm{CH}_{3} \mathrm{OOH}$, which would be consistent with an overestimate of (R3). They also indicated a factor of 2 underestimate of $\mathrm{CH}_{2} \mathrm{O}$ (common product of $\mathrm{CH}_{3} \mathrm{O}_{2}$ degradation pathways) [Heikes et al., 2001]. As discussed by Heikes et al. [2001], the latter discrepancy suggests a major contribution from VOCs other than methane to the supply of $\mathrm{CH}_{3} \mathrm{O}_{2}$. This would provide an alternate explanation for increasing the methanol source from the $\mathrm{CH}_{3} \mathrm{O}_{2}$ self-reaction.

\section{Discussion: Constraints on the Methanol Budget From Atmospheric Observations}

[54] Observed atmospheric concentrations of methanol are consistent with the view that plant growth provides the principal global source. Laboratory and field studies indicate a factor of 2-3 decrease in this source from young to mature leaves [McDonald and Fall, 1993; NemecekMarshall et al., 1995; Karl et al., 2003]. We find that this is consistent with the observed seasonal variation of methanol concentrations at northern midlatitudes. A global plant growth source of $128 \mathrm{Tg} \mathrm{yr}^{-1}$, computed in our model using the NPP-based algorithm of Galbally and Kirstine [2002], provides an overall unbiased simulation at northern midlatitudes. The tropics are the largest global contributor to this source but observations there are few. Data for tropical South America [Williams et al., 2001; Kesselmeier et al., 2002] suggest that our model source is too high, while data for Costa Rica [Karl et al., 2004] are consistent with the model. More work is clearly needed to improve understanding of methanol emission from tropical land ecosystems. The model also predicts high surface air concentrations $(>10$ ppbv) over Siberia in July, reflecting a large seasonal plant growth source as well as a long continental fetch. Measurements in this region would be of great value.

[55] The net flux of methanol from the terrestrial biosphere in the model is $96 \mathrm{Tg} \mathrm{yr}^{-1}$ including $128 \mathrm{Tg} \mathrm{yr}^{-1}$

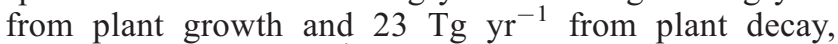
balanced by $55 \mathrm{Tg} \mathrm{yr}^{-1}$ dry deposition to land (Table 1). The atmospheric observations offer limited constraints for separating these three different terms. The plant growth source appears to be responsible for the observed decline of 
concentrations from spring to fall, while the deposition sink appears to be responsible for the observed diurnal variation of concentrations as well as the decline at northern latitudes over the course of the winter.

[56] Observed concentrations of methanol over the South Pacific during the PEM-Tropics B aircraft mission (0.6$1.2 \mathrm{ppbv}$ ) are much higher than would be expected from the terrestrial vegetation source and show little vertical or longitudinal structure. Diffuse atmospheric production of methanol from the $\mathrm{CH}_{3} \mathrm{O}_{2}$ self-reaction (R1), where $\mathrm{CH}_{3} \mathrm{O}_{2}$ originates mainly from methane oxidation, is the principal model source in the region and contributes a $0.2-0.4 \mathrm{ppbv}$ model background. Our computed global magnitude of this source $\left(38 \mathrm{Tg} \mathrm{yr}^{-1}\right)$ is larger than previous estimates (18$31 \mathrm{Tg} \mathrm{yr}^{-1}$ ) but still would need to be doubled to approach the South Pacific observations. Methanol observations over the remote north tropical and subtropical Pacific (TRACE-P and ITCT $2 \mathrm{~K} 2$ aircraft missions) also suggest that atmospheric production of methanol from (R1) in the model is too low.

[57] Computation of the methanol source from (R1) in global tropospheric chemistry models is affected by uncertainties in the concentration of $\mathrm{CH}_{3} \mathrm{O}_{2}$ and in the branching ratio of $\mathrm{CH}_{3} \mathrm{O}_{2}$ reactions. A doubling to 50-100 $\mathrm{Tg} \mathrm{yr}^{-1}$ does not appear to be inconsistent with independent constraints, and is specifically within the constraints offered by ancillary PEM-Tropics $\mathrm{B}$ observations of $\mathrm{CH}_{3} \mathrm{OOH}$ and $\mathrm{CH}_{2} \mathrm{O}$. It could reflect errors in kinetic rate constants, or the presence of VOCs other than methane in the remote marine atmosphere to provide sources of $\mathrm{CH}_{3} \mathrm{O}_{2}$. Some observations of aldehydes in remote marine air [Heikes et al., 2001; Singh et al., 2001, 2004] suggest the latter, and imply a more active organic photochemistry than is currently described in models, while other observations are more consistent with current understanding [Fried et al., 2003]. Measurements of $\mathrm{HO}_{2}$ and total peroxy $\left(\mathrm{HO}_{2}+\right.$ $\mathrm{CH}_{3} \mathrm{O}_{2}+\mathrm{RO}_{2}$ ) radical concentrations by the chemical amplifier method during TRACE-P indicated concentration ratios of organic peroxy radicals to $\mathrm{HO}_{2}$ that are consistent with current models [Cantrell et al., 2003], but there is substantial uncertainty in these measurements. Direct measurements of $\mathrm{CH}_{3} \mathrm{O}_{2}$ concentrations in the remote atmosphere are needed.

[58] Our model yields a global mean atmospheric lifetime for methanol of 7 days, with losses from gas-phase reaction with $\mathrm{OH}(63 \%$ of total loss $)$, dry deposition to land $(26 \%)$, wet deposition (6\%), and uptake by the ocean $(5 \%)$. Aqueous-phase oxidation by $\mathrm{OH}(\mathrm{aq})$ in clouds is negligible. The general ability of the model to reproduce the observed variability of methanol concentrations (cf. Figure 7) suggests a relatively narrow range of uncertainty in the lifetime, $5-10$ days. Chemical loss of methanol by reaction with $\mathrm{OH}$ is uncertain by only about $30 \%$ [Jimenez et al., 2003] and most likely represents the dominant global sink for methanol. The low methanol concentrations observed at high northern latitudes in winter imply an additional nonphotochemical sink, which we attribute in the model to dry deposition to land. This attribution is supported by observations of methanol fluxes and of the diurnal variation of methanol concentrations at vegetated sites, although there is considerable variability from site to site. Heterogeneous loss in aerosols and clouds could provide an alternate explana- tion for the observed wintertime depletion of methanol but is not supported by independent evidence. Aircraft observations of vertical profiles over the oceans suggest that ocean uptake is only a weak sink, although ship data from the AOE-2001 summertime Arctic campaign suggest the possibility of rapid local uptake. Wet deposition, constrained by the Henry's law solubility for methanol, is only a weak sink.

[59] Our best estimate of the global source of methanol (after allowing for doubling of atmospheric production to $\left.76 \mathrm{Tg} \mathrm{yr}^{-1}\right)$ is $240 \mathrm{Tg} \mathrm{yr}^{-1}$. Singh et al. [2004] estimated a

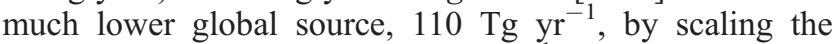
global acetone source of $95 \mathrm{Tg} \mathrm{yr}^{-1}$ from Jacob et al. [2002] to the mean acetone/methanol concentration ratio of $2.1 \mathrm{~g} \mathrm{~g}^{-1}$ that they measured in TRACE-P and to the ratio of lifetimes of acetone (15 days, from Jacob et al. [2002]) and methanol (9 days, from Heikes et al. [2002]). However, the concentration ratio measured in TRACE-P is lower than the expected global mean because of the large regional anthropogenic contribution to acetone [Jacob et al., 2002] and the relatively weak biogenic methanol emission from East Asia at that time of year. A methanol source of $110 \mathrm{Tg}$ $\mathrm{yr}^{-1}$ in our model would result in a low bias relative to observations. Singh et al. [2004] acknowledge that their emission estimate is subject to large uncertainty.

\section{Implications for Atmospheric Chemistry}

[60] Our budget implies a minor but nonnegligible role for methanol in global tropospheric chemistry. Oxidation of methanol by $\mathrm{OH}$ produces $\mathrm{CH}_{2} \mathrm{OH}$ (major pathway) and $\mathrm{CH}_{3} \mathrm{O}$ (minor), which both go on to produce $\mathrm{CH}_{2} \mathrm{O}$ and $\mathrm{HO}_{2}$ [Jimenez et al., 2003]. The global tropospheric rate of methanol oxidation calculated in our model on a per-carbon

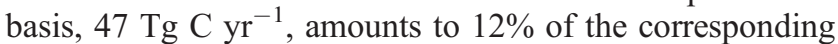
value of $380 \mathrm{Tg} \mathrm{C} \mathrm{yr}^{-1}$ for methane oxidation [IPCC, 2001]. Methanol provides a significant source of $\mathrm{CH}_{2} \mathrm{O}$ both in the continental boundary layer [Riemer et al., 1998; Palmer et al., 2003a] and in the remote troposphere [Heikes et al., 2001]. The production of CO from methanol oxidation amounts to $4-6 \%$ of the global CO source of $1800-$ $2700 \mathrm{Tg} \mathrm{yr}^{-1}$ (Duncan et al., submitted manuscript, 2004). Inclusion of methanol in GEOS-CHEM at the levels simulated here decreases the global tropospheric $\mathrm{OH}$ concentration by $2 \%$, an effect similar to that reported previously by Tie et al. [2003]. Regional variations in this effect on $\mathrm{OH}$ are discussed by Tie et al. [2003] and are relatively small.

[61] Acknowledgments. This work was funded at Harvard by the Atmospheric Chemistry Program of the U.S. National Science Foundation. H. B. Singh acknowledges support from the NASA IDS program. A. Wisthaler and A. Hansel thank Caroline Leck (MISU), the coordinator of the Atmospheric Program of AOE-2001, and Ulrich Poeschl (TU-Munich), the coordinator of the Zugspitze SCAVEX Program. The GEOS-CHEM model is managed at Harvard University with support from the NASA Atmospheric Chemistry Modeling and Analysis Program. We thank the reviewers for their very useful comments.

\section{References}

Andreae, M. O., and P. Merlet (2001), Emission of trace gases and aerosols from biomass burning, Global Biogeochem. Cycles, 15, 955-966.

Atlas, E. L., B. A. Ridley, and C. A. Cantrell (2003), The Tropospheric Ozone Production about the Spring Equinox (TOPSE) Experiment: Introduction, J. Geophys. Res., 108(D4), 8353, doi:10.1029/ 2002JD003172. 
Bergamaschi, P., R. Hein, M. Heimann, and P. J. Crutzen (2000), Inverse modeling of the global $\mathrm{CO}$ cycle: 1 . Inversion of $\mathrm{CO}$ mixing ratios, J. Geophys. Res., 105, 1909-1927.

Bey, I., D. J. Jacob, R. M. Yantosca, J. A. Logan, B. D. Field, A. M. Fiore, Q. Li, H. Liu, L. J. Mickley, and M. G. Schultz (2001), Global modeling of tropospheric chemistry with assimilated meteorology: Model description and evaluation, J. Geophys. Res., 106, 23,073-23,096.

Boudries, H., J. W. Bottenheim, C. Guimbaud, A. M. Grannas, P. B Shepson, S. Houdier, S. Perrier, and F. Dominé (2002), Distribution and trends of oxygenated hydrocarbons in the high Arctic derived from measurements in the atmospheric boundary layer and interstitial snow air during the ALERT2000 field campaign, Atmos. Environ., 36, $2573-2583$

Cantrell, C. A., G. D. Edwards, S. Stephens, L. Mauldin, E. Kosciuch, M. Zondlo, and F. Eisele (2003), Peroxy radical observations using chemical ionization mass spectrometry during TOPSE, J. Geophys. Res., 108(D6), 8371, doi:10.1029/2002JD002715.

Carlos-Cuellar, S., P. Li, A. P. Christensen, B. J. Krueger, C. Burrichter, and V. H. Grassian (2003), Heterogeneous uptake kinetics of volatile organic compounds on oxide surfaces using a Knudsen cell reactor: Adsorption of acetic acid, formaldehyde, and methanol on $\alpha-\mathrm{Fe}_{2} \mathrm{O}_{3}, \alpha-\mathrm{Al}_{2} \mathrm{O}_{3}$, and $\mathrm{SiO}_{2}$, J. Phys. Chem. A, 107, 4250-4261.

Carpenter, L. J., A. C. Lewis, J. R. Hopkins, K. A. Read, I. D. Longley, and M. W. Gallagher (2004), Uptake of methanol to the North Atlantic Ocean surface, Global Biogeochem. Cycles, 18, GB4027, doi:10.1029/ 2004GB002294.

Christian, T. J., B. Kleiss, R. J. Yokelson, R. Holzinger, P. J. Crutzen, W. M Hao, B. H. Saharjo, and D. E. Ward (2003), Comprehensive laboratory measurements of biomass-burning emissions: 1. Emissions from Indonesian, African, and other fuels, J. Geophys. Res., 108(D23), 4719, doi:10.1029/2003JD003704.

Crawford, J. H., et al. (2004), Relationship between Measurements of Pollution in the Troposphere (MOPITT) and in situ observations of CO based on a large-scale feature sampled during TRACE-P, J. Geophys. Res., 109, D15S04, doi:10.1029/2003JD004308.

Crutzen, P. J., and M. G. Lawrence (2000), The impact of precipitation scavenging on the transport of trace gases: A 3-dimensional model sensitivity study, J. Atmos. Chem., 37, 81-112.

de Gouw, J. A., P. D. Goldan, C. Warneke, W. C. Kuster, J. M. Roberts, M. Marchewka, S. B. Bertman, A. A. P. Pszenny, and W. C. Keene (2003), Validation of proton transfer reaction-mass spectrometry (PTR-MS) measurements of gas-phase organic compounds in the atmosphere during the New England Air Quality Study (NEAQS) in 2002, J. Geophys. Res., 108(D21), 4682, doi:10.1029/2003JD003863.

Duncan, B. N., R. V. Martin, A. C. Staudt, R. Yevich, and J. A. Logan (2003), Interannual and seasonal variability of biomass burning emissions constrained by satellite observations, J. Geophys. Res., 108(D2), 4100, doi:10.1029/2002JD002378.

Elliot, A. J., and D. R. McCracken (1989), Effect of temperature on $\mathrm{O}^{-}$ reactions and equilibria: A pulse radiolysis study, Int. J. Appl. Radiat Instrum. C, 33, 69-74

Fiore, A., D. J. Jacob, H. Liu, R. M. Yantosca, T. D. Fairlie, and Q. Li (2003), Variability in surface ozone background over the United States: Implications for air quality policy, J. Geophys. Res., 108(D24), 4787, doi:10.1029/2003JD003855.

Fried, A., et al. (2003), Airborne tunable diode laser measurements of formaldehyde during TRACE-P: Distributions and box model comparisons, J. Geophys. Res., 108(D20), 8798, doi:10.1029/2003JD003451.

Galbally, I. E., and W. Kirstine (2002), The production of methanol by flowering plants and the global cycle of methanol, J. Atmos. Chem. 43, $195-229$

Goldan, P. D., W. C. Kuster, F. C. Fehsenfeld, and S. A. Montzka (1995), Hydrocarbon measurements in the southeastern United States: The Rural Oxidants in the Southern Environment (ROSE) program 1990, J. Geophys. Res., 100, 35,945-35,963.

Guenther, A., et al. (1995), A global model of natural volatile organic compound emissions, J. Geophys. Res., 100, 8873-8892.

Heald, C. L., D. J. Jacob, P. I. Palmer, M. J. Evans, G. W. Sachse, H. B. Singh, and D. R. Blake (2003a), Biomass burning emission inventory with daily resolution: Application to aircraft observations of Asian outflow, J. Geophys. Res., 108(D21), 8811, doi:10.1029/2002JD003082.

Heald, C. L., et al. (2003b), Asian outflow and trans-Pacific transport of carbon monoxide and ozone pollution: An integrated satellite, aircraft, and model perspective, J. Geophys. Res., 108(D24), 4804, doi:10.1029/ 2003JD003507.

Heikes, B., et al. (2001), Formaldehyde over the central Pacific during PEM-Tropics B, J. Geophys. Res., 106, 32,717-32,732.

Heikes, B. G., et al. (2002), Atmospheric methanol budget and ocean implication, Global Biogeochem. Cycles, 16(4), 1133, doi:10.1029/ 2002 GB001895.
Holzinger, R., A. Jordan, A. Hansel, and W. Lindinger (2001), Methanol measurements in the lower troposphere near Innsbruck $\left(047^{\circ} 16^{\prime} \mathrm{N}\right.$; $011^{\circ} 24^{\prime}$ E), Austria, Atmos. Environ., 35, 2525-2532.

Holzinger, R., J. Williams, G. Salisbury, T. Klupfel, M. de Reus, M. Traub, P. J. Crutzen, and J. Lelieveld (2004), Oxygenated compounds in aged biomass burning plumes over the eastern Mediterranean: Evidence for strong secondary production of methanol and acetone, Atm. Chem. Phys. Discuss., 4, 6321-6340.

Hudson, P. K., M. A. Zondlo, and M. A. Tolbert (2002), The interaction of methanol, acetone, and acetaldehyde with ice and nitric acid-doped ice: Implications for cirrus clouds, J. Phys. Chem., 106, 2882-2888.

Intergovernmental Panel on Climate Change (IPCC) (2001), Climate Change 2001: The Scientific Basis, edited by J. T. Houghton et al., Cambridge Univ. Press, New York.

Iraci, L. T., A. M. Essin, and D. M. Golden (2002), Solubility of methanol in low-temperature aqueous sulfuric acid and implications for atmospheric particle composition, J. Phys. Chem., 106, 4054-4060.

Jacob, D. J. (1986), The chemistry of $\mathrm{OH}$ in remote clouds and its role in the production of formic acid and peroxymonosulfate, J. Geophys. Res., 91, 9807-9826.

Jacob, D. J., B. D. Field, E. M. Jin, I. Bey, Q. Li, J. A. Logan, R. M. Yantosca, and H. B. Singh (2002), Atmospheric budget of acetone, J. Geophys. Res., 107(D10), 4100, doi:10.1029/2001JD000694

Jacob, D. J., J. H. Crawford, M. M. Kleb, V. S. Connors, R. J. Bendura, J. L. Raper, G. W. Sachse, J. C. Gille, L. Emmons, and C. L. Heald (2003), Transport and Chemical Evolution over the Pacific (TRACE-P) aircraft mission: Design, execution, and first results, J. Geophys. Res., 108(D20), 9000, doi:10.1029/2002JD003276.

Jaeglé, L., et al. (2000), Photochemistry of $\mathrm{HO}_{\mathrm{x}}$ in the upper troposphere at northern midlatitudes, J. Geophys. Res., 105, 3877-3892.

Jet Propulsion Laboratory (JPL) (2003), Chemical Kinetics and Photochemical Data for Use in Atmospheric Studies, JPL Publ. No. 02-25, Jet Propul. Lab., Pasadena, Calif.

Jimenez, E., M. K. Gilles, and A. R. Ravishankara (2003), Kinetics of the reactions of the hydroxyl radical with $\mathrm{CH}_{3} \mathrm{OH}$ and $\mathrm{C}_{2} \mathrm{H}_{5} \mathrm{OH}$ between 235 and $360 \mathrm{~K}, \mathrm{~J}$. Photochem. Photobiol. A, 157, 237-245.

Kane, S. M., and M.-T. Leu (2001), Uptake of methanol vapor in sulfuric acid solutions, J. Phys. Chem., 105, 1411-1415.

Karl, T., A. Guenther, C. Spirig, A. Hansel, and R. Fall (2003), Seasonal variation of biogenic VOC emissions above a mixed hardwood forest in northern Michigan, Geophys. Res. Lett., 30(23), 2186, doi:10.1029/ 2003 GL018432.

Karl, T., M. Potosnak, A. Guenther, D. Clark, J. Walker, J. D. Herrick, and C. Geron (2004), Exchange processes of volatile organic compounds above a tropical rain forest: Implications for modeling tropospheric chemistry above dense vegetation, J. Geophys. Res., 109, D18306, doi:10.1029/2004JD004738.

Kesselmeier, J., et al. (2002), Concentrations and species composition of atmospheric volatile organic compounds (VOCs) as observed during the wet and dry season in Rondônia (Amazonia), J. Geophys. Res., 107(D20), 8053, doi:10.1029/2000JD000267.

Kiley, C. M., et al. (2003), An intercomparison and evaluation of aircraftderived and simulated CO from seven chemical transport models during the TRACE-P experiment, J. Geophys. Res., 108(D21), 8819, doi:10.1029/2002JD003089.

Lelieveld, J., et al. (2002), Global air pollution crossroads over the Mediterranean, Science, 298, 794-798.

Li, Q., D. J. Jacob, R. M. Yantosca, C. L. Heald, H. B. Singh, M. Koike, Y. Zhao, G. W. Sachse, and D. G. Streets (2003), A global threedimensional model analysis of the atmospheric budgets of $\mathrm{HCN}$ and $\mathrm{CH}_{3} \mathrm{CN}$ : Constraints from aircraft and ground measurements, J. Geophys. Res., 108(D21), 8827, doi:10.1029/2002JD003075.

Liu, H., D. J. Jacob, I. Bey, and R. M. Yantosca (2001), Constraints from ${ }^{210} \mathrm{~Pb}$ and ${ }^{7} \mathrm{Be}$ on wet deposition and transport in a global threedimensional chemical tracer model driven by assimilated meteorological fields, J. Geophys. Res., 106, 12,109-12,128.

Liu, H., D. J. Jacob, I. Bey, R. M. Yantosca, B. N. Duncan, and G. W. Sachse (2003), Transport pathways for Asian pollution outflow over the Pacific: Interannual and seasonal variations, J. Geophys. Res., 108(D20), 8786, doi:10.1029/2002JD003102.

Madronich, S., and J. G. Calvert (1990), Permutation reactions of organic peroxy radicals in the troposphere, J. Geophys. Res., 95, 5697-5716.

Mari, C., D. J. Jacob, and P. Bechtold (2000), Transport and scavenging of soluble gases in a deep convective cloud, J. Geophys. Res., 105, 22,255$22,267$.

Martin, R. V., et al. (2002), An improved retrieval of tropospheric nitrogen dioxide from GOME, J. Geophys. Res., 107(D20), 4437, doi:10.1029/ 2001JD001027.

Martin, R. V., D. J. Jacob, R. M. Yantosca, M. Chin, and P. Ginoux (2003), Global and regional decreases in tropospheric oxidants from photochemi- 
cal effects of aerosols, J. Geophys. Res., 108(D3), 4097, doi:10.1029/ 2002JD002622.

McDonald, R. C., and R. Fall (1993), Detection of substantial emissions of methanol from plants to the atmosphere, Atmos. Environ., 27, 17091713

Nemecek-Marshall, M., R. C. MacDonald, J. J. Franzen, C. L. Wojciechowski, and R. Fall (1995), Methanol emission from leaves, Plant Physiol., 108, 1359-1368.

Nowak, J. B., et al. (2004), Gas-phase chemical characteristics of Asian emission plumes observed during ITCT $2 \mathrm{~K} 2$ over the eastern North Pacific Ocean, J. Geophys. Res., 109, D23S19, doi:10.1029/ 2003JD004488

Olivier, J. G. J., A. F. Bouwman, C. W. M. Van der Maas, and J. J. M. Berdowski (1994), Emission Database for Global Atmospheric Research (EDGAR), Environ. Monit. Assess., 31, 93-106.

Olson, J. R., et al. (2001), Seasonal differences in the photochemistry of the South Pacific: A comparison of observations and model results from PEM Tropics A and B, J. Geophys. Res., 106, 32,749-32,766.

Palmer, P. I., D. J. Jacob, A. M. Fiore, R. V. Martin, K. Chance, and T. P. Kurosu (2003a), Mapping isoprene emissions over North America using formaldehyde column observations from space, J. Geophys. Res., 108(D6), 4180, doi:10.1029/2002JD002153.

Palmer, P. I., D. J. Jacob, D. B. A. Jones, C. L. Heald, R. M. Yantosca, J. A. Logan, G. W. Sachse, and D. G. Streets (2003b), Inverting for emissions of carbon monoxide from Asia using aircraft observations over the western Pacific, J. Geophys. Res., 108(D21), 8828, doi:10.1029/ 2003JD003397.

Pétron, G., C. Granier, B. Khattatov, J. Lamarque, V. Yudin, J. Müller, and J. Gille (2002), Inverse modeling of carbon monoxide surface emissions using Climate Monitoring and Diagnostics Laboratory network observations, J. Geophys. Res., 107(D24), 4761, doi:10.1029/2001JD001305.

Potter, C. S., J. T. Randerson, C. B. Field, P. A. Matson, P. M. Vitousek, H. A. Mooney, and S. A. Klooster (1993), Terrestrial ecosystem production: A process model based on global satellite and surface data, Global Biogeochem. Cycles, 7, 811-841.

Randerson, J. T., M. V. Thompson, T. J. Conway, I. Y. Fung, and C. B. Field (1997), The contribution of terrestrial sources and sinks to trends in the seasonal cycle of atmospheric carbon dioxide, Global Biogeochem. Cycles, 11, 535-560.

Riemer, D., et al. (1998), Observations of nonmethane hydrocarbons and oxygenated volatile organic compounds at a rural site in the southeastern United States, J. Geophys. Res., 103, 28,111-28,128.

Salisbury, G., et al. (2003), Ground-based PTR-MS measurements of reactive organic compounds during the MINOS campaign in Crete, July-August 2001, Atmos. Chem. Phys. Discuss., 3, 911-948.

Schade, G. W., and A. H. Goldstein (2001), Fluxes of oxygenated volatile organic compounds from a ponderosa pine plantation, J. Geophys. Res. $106,3111-3123$.

Schneider, H. R., D. B. A. Jones, M. B. McElroy, and G.-Y. Shi (2000) Analysis of residual mean transport in the stratosphere: 1 . Model description and comparison with satellite data, J. Geophys. Res., 105, 19,99120,011

Singh, H. B., M. Kanakidou, P. J. Crutzen, and D. J. Jacob (1995), High concentrations and photochemical fate of oxygenated hydrocarbons in the global troposphere, Nature, 378, 50-54

Singh, H. B., et al. (2000), Distribution and fate of selected oxygenated organic species in the troposphere and lower stratosphere over the North Atlantic, J. Geophys. Res., 105, 3795-3805.

Singh, H. B., Y. Chen, A. C. Staudt, D. J. Jacob, D. R. Blake, B. G. Heikes, and J. Snow (2001), Evidence from the South Pacific troposphere for large global abundances and sources of oxygenated organic compounds, Nature, 410, 1078-1081.

Singh, H. B., A. Tabazadeh, M. J. Evans, B. D. Field, D. J. Jacob, G. Sachse, J. H. Crawford, R. Shetter, and W. H. Brune (2003a), Oxygenated volatile organic chemicals in the oceans: Inferences and implications based on atmospheric observations and air-sea exchange models, Geophys. Res. Lett., 30(16), 1862, doi:10.1029/2003GL017933.

Singh, H. B., et al. (2003b), In situ measurements of $\mathrm{HCN}$ and $\mathrm{CH}_{3} \mathrm{CN}$ over the Pacific Ocean: Sources, sinks, and budgets, J. Geophys. Res., 108(D20), 8795, doi:10.1029/2002JD003006.

Singh, H. B., et al. (2004), Analysis of the atmospheric distribution, sources, and sinks of oxygenated volatile organic chemicals based on measurements over the Pacific during TRACE-P, J. Geophys. Res., 109, D15S07, doi:10.1029/2003JD003883.

Suntharalingam, P., D. J. Jacob, P. I. Palmer, J. A. Logan, R. M. Yantosca Y. Xiao, M. J. Evans, D. G. Streets, S. L. Vay, and G. W. Sachse (2004) Improved quantification of Chinese carbon fluxes using $\mathrm{CO}_{2} / \mathrm{CO}$ correlations in Asian outflow, J. Geophys. Res., 109, D18S18, doi:10.1029 2003JD004362.
Tabazadeh, A., R. J. Yokelson, H. B. Singh, P. V. Hobbs, J. H. Crawford, and L. T. Iraci (2004), Heterogeneous chemistry involving methanol in tropospheric clouds, Geophys. Res. Lett., 31, L06114, doi:10.1029/ 2003GL018775.

Tan, W. W., M. A. Geller, S. Pawson, and A. da Silva (2004), A case study of excessive subtropical transport in the stratosphere of a data assimilation system, J. Geophys. Res., 109, D11102, doi:10.1029/ 2003JD004057.

Tie, X., A. Guenther, and E. Holland (2003), Biogenic methanol and its impacts on tropospheric oxidants, Geophys. Res. Lett., 30(17), 1881, doi:10.1029/2003GL017167.

Tyndall, G. S., R. A. Cox, C. Granier, R. Lesclaux, G. K. Moortgaat, M. J. Pilling, A. R. Ravishankara, and T. J. Wallington (2001), Atmospheric chemistry of small organic peroxy radicals, J. Geophys. Res., 106, $12,157-12,182$.

von Kuhlmann, R., M. G. Lawrence, P. J. Crutzen, and P. J. Rasch (2003a), A model for studies of tropospheric ozone and nonmethane hydrocarbons: Model description and ozone results, J. Geophys. Res., 108(D9), 4294, doi:10.1029/2002JD002893.

von Kuhlmann, R., M. G. Lawrence, P. J. Crutzen, and P. J. Rasch (2003b), A model for studies of tropospheric ozone and nonmethane hydrocarbons: Model evaluation of ozone-related species, J. Geophys. Res., 108(D23), 4729, doi:10.1029/2002JD003348.

Wang, Y., D. J. Jacob, and J. A. Logan (1998), Global simulation of tropospheric $\mathrm{O}_{3}-\mathrm{NO}_{\mathrm{x}}$-hydrocarbon chemistry: 1. Model formulation, J. Geophys. Res., 103, 10,713-10,726.

Warneke, C., T. Karl, H. Judmaier, A. Hansel, A. Jordan, and W. Lindinger (1999), Acetone, methanol, and other partially oxidized volatile organic emissions from dead plant matter by abiological processes: Significance for atmospheric $\mathrm{HO}_{\mathrm{x}}$ chemistry, Global Biogeochem. Cycles, 13, 9-17.

Warneke, C., S. L. Luxembourg, J. A. de Gouw, H. J. I. Rinne, A. B. Guenther, and R. Fall (2002), Disjunct eddy covariance measurements of oxygenated volatile organic compounds fluxes from an alfalfa field before and after cutting, J. Geophys. Res., 107(D8), 4067, doi:10.1029/ 2001JD000594.

Williams, J., U. Poschl, P. J. Crutzen, A. Hansel, R. Holzinger, C. Warneke, W. Lindinger, and J. Lelieveld (2001), An atmospheric chemistry interpretation of mass scans obtained from a proton transfer mass spectrometer flown over the tropical rainforest of Surinam, J. Atmos. Chem., 38 , $133-166$.

Winkler, A. K., N. S. Holmes, and J. N. Crowley (2002), Interaction of methanol, acetone, and formaldehyde with ice surfaces between 198 and 223 K, Phys. Chem. Chem. Phys, 4, 5270-5275.

Wisthaler, A., A. Hansel, R. R. Dickerson, and P. J. Crutzen (2002), Organic trace gas measurements by PTR-MS during INDOEX 1999, J. Geophys. Res., 107(D19), 8024, doi:10.1029/2001JD000576.

Yevich, R., and J. A. Logan (2003), An assessment of biofuel use and burning of agricultural waste in the developing world, Global Biogeochem. Cycles, 17(4), 1095, doi:10.1029/2002GB001952.

Yokelson, R. J., J. G. Goode, D. E. Ward, R. A. Susott, R. E. Babbitt, D. D. Wade, I. Bertschi, D. W. T. Griffith, and W. M. Hao (1999), Emissions of formaldehyde, acetic acid, methanol, and other trace gases from biomass fires in North Carolina measured by airborne Fourier transform infrared spectroscopy, J. Geophys. Res., 104, 30,109-30,125.

Yokelson, R. J., I. T. Bertschi, T. J. Christian, P. V. Hobbs, D. E. Ward, and W. M. Hao (2003), Trace gas measurements in nascent, aged, and cloudprocessed smoke from African savanna fires by airborne Fourier transform infrared spectroscopy (AFTIR), J. Geophys. Res., 108(D13), 8478, doi:10.1029/2002JD002322.

D. R. Blake, Department of Chemistry, University of California, 570 Rowland Hall, Irvine, CA 92697-2025, USA.

J. de Gouw and C. Warneke, NOAA Aeronomy Laboratory, 325 Broadway, R/AL7, Boulder, CO 80305, USA

B. D. Field and D. J. Jacob, Division of Engineering and Applied Science, Harvard University, Pierce Hall, 29 Oxford St., Cambridge, MA 02138, USA. (djacob@fas.harvard.edu)

A. Guenther, Atmospheric Chemistry Division, National Center for Atmospheric Research, PO Box 3000, Boulder, CO 80307-3000, USA

A. Hansel and A. Wisthaler, Institute of Ion Physics, University of Innsbruck, Technikerstrasse 25, A-6020 Innsbruck, Austria.

Q. Li, Jet Propulsion Laboratory, M/S 183-501, 4800 Oak Grove Dr., Pasadena, CA 91109, USA.

H. B. Singh, NASA Ames Research Center, Mail Stop 245-5, Moffett Field, CA 94035, USA 